\title{
Perspectives on Administrative Justice - CONTEMPORARY CHALlENGES AND OPPORTUNITIES - AN INTRODUCTION
}

\author{
Ricardo Perlingeiro ${ }^{1}$ \\ Fluminense Federal University and Estácio de Sá University, Brazil \\ Anne Richardson Oakes ${ }^{2}$ \\ Birmingham City University, United Kingdom
}

\begin{abstract}
Recognition of human rights protection as a central theme of concern has enriched constitutional discourse but diverted attention from the positive role of the executive in the promotion and delivery of justice. The papers abstracted in this collection seek to redress this contemporary imbalance in public law theory and scholarship with a variety of fresh perspectives on the themes and mechanisms of administrative justice. Presented virtually to the Law and Society 2020 annual meeting at a roundtable organised by Professors Anne Richardson Oakes of the Centre for American Legal Studies Birmingham City University U.K. and Ricardo Perlingeiro of Estácio de Sá University, Rio de Janeiro, the papers represent work in progress and come out of on an ongoing project carried out jointly with the Post-Graduate Law Program of the University Estácio de Sá/PPGD-Unesa (with support of the Post-Graduate Administrative Justice Program of the Fluminense Federal University/PPGJA-UFF) in partnership with the Centre for American Legal Studies (School of Law at Birmingham City University).
\end{abstract}

The overall aim of the project is to provide comparative perspectives on the judicial role in disputes between citizens and the administration and thereby contribute to debate concerning boundaries and competencies under a constitutional regime of separation of powers. These issues assume central importance in the context of so-called Chevron deference (Chevron U.S.A., Inc. v. Natural Resources Defense Council, Inc., 467 U.S. 83 (1984) and related doctrines of U.S. administrative law which require judicial attention to the point of deference to agency interpretations of the meanings of the statutes under which they operate and the rules that they have themselves promulgated (Auer v. Robbins, 519 U.S. 452 (1997) and Kisor v. Wilkie, No. 18-15, 588 U.S. (2019). They are more fully discussed in a series of essays authored by contributors to the project and presented in a forthcoming publication entitled Judicial Deference and the Administrative State: Comparative Perspectives (Oakes \& Perlingeiro Eds.).

Contributors to this collection bring a range of perspectives from civil and common law jurisdictions in the wider Americas and Europe to address related but sometimes overlooked issues concerning the delivery and purpose of administrative justice. Themes discussed include the role of administrative/executive justice in promoting social stability; legitimacy and

\footnotetext{
${ }^{1}$ Full Professor of the Faculty of Law of Fluminense Federal University (Niterói, Rio de Janeiro). Federal Appellate Judge (Desembargador Federal) of the Federal Regional Court of the $2^{\text {nd }}$ Region (Rio de Janeiro). Associate Professor in Comparative Public Law in the Post-Graduate Law Program of the University Estácio de Sá / PPGD-Unesa. ricardo.perlingeiro@estacio.br

${ }^{2}$ Director, Centre for American Legal Studies, Birmingham City University. anne.oakes@ bcu.ac.uk
} 
democratic accountability; inculcating a culture of procedural fairness; the desirability of a general requirement to give reasons, and the relationship between executive and judicial authority. Fiero (CIDE Mexico) argues that against a background of a rising tide of populism, courts facilitate public involvement in the administrative decision-making process and provide mechanisms for government accountability and control against abuse of powers. In so doing they promote democratic participation and engagement and represent an important aspect of the institutional framework of social stability. Garcia (CIDE Mexico), Di-Gioia (BCU, U.K.) and Valle (Estácio, Brazil) interrogate the executive/judiciary interface with specific perspectives from the United States and Latin America. Di-Gioia examines recent U.S. Supreme Court decisions concerning the non-delegation doctrine to uncover the constitutional underpinnings of the relationship between the judiciary and the U.S. administrative state. Garcia examines reparations cases in Argentina, Colombia and Mexico to draw parallels and distinctions between the approaches of two regional human rights courts, the European Court of Human Rights and Inter-American Court of Human Rights. Valle focusses on judicial responses to policy choices in the context of access to health in Brazil and considers the argument that these interventions in administrative strategical choices raise questions that are not merely about competence in the sense of expertise but speak directly to the role of the state and are fundamentally political in a contemporary democracy. Oakes (BCU, U.K.) takes up this theme in relation to the decisions of the U.K. Supreme Court in R. (Miller) v. Sec'y of State for Exiting the European Union (Miller 1) [2017] UKSC 5 and $R$ (Miller) v. Prime Minister [2019] UKSC 41 (Miller II). Both decisions were prompted by the decision of the British people to leave the European Union. They put in issue the role of the U.K. highest court as a court of common law constitutionalism and have raised the prospect of executive action to curb judicial overreach. The author predicts that these cases may, in retrospect, be seen to be a turning point away from judicial constitutionalism in favour of a return to an agenda of promoting principles of good administration. Jansen (BCU, U.K.) develops the theme of fairness concerning the allocation of resources as a goal of administrative law and locates an answer in the formulation of and adherence to policy. He contrasts the requirements on the General Administrative Law Act of the Netherlands which mandates that policy be followed except in exceptional circumstances with the U.K. preference for individualised decisionmaking. He argues that both approaches depend upon the giving of reasons and that this is a key component of procedural and substantive fairness in administrative decision-making generally.

This rich collection of abstracts was presented at a time of unprecedented change brought about by the Coronavirus pandemic which has touched virtually every aspect of public and private life and massively increased the importance of the administrative state. The extent to which all or any of these changes will be permanent is as yet unclear. The important issues discussed here will guide our thinking as we continue to explore new and existing challenges to the relationship of the judiciary and the modern administrative state.

Niterói/Birmingham. 


\title{
Administrative Courts \\ a Defense Against Populism
}

\author{
Ana Fierro ${ }^{1}$ \\ Centro de Investigación y Docencia Económica (CIDE), México
}

\begin{abstract}
Over the past two decades, populist governments have proliferated in America. These governments are characterized by reducing to mere formalism the procedures of control of the rule and intervene in the judiciary and administrative courts. Modern society worked hard to achieve legal systems based on the rule of law, in order to prevent citizens from being subject to the will of one leader. In our legal systems administrative courts play a fundamental role improving state bodies. This paper explores the use of administrative courts as accountability mechanisms that protect the rule of law. We suggest that administrative courts are powerful procedures for accountability and control against abuse of powers. Finally, we recommend states should broaden access to these mechanisms, given the fact that administrative trails are still very restricted to most of the citizens."
\end{abstract}

Keywords: Accountability, administrative courts, constitution, human rights, rule of law, nullity trial, state liability trial, judicial control, populism.

Over the past two decades, populist governments have proliferated in America. The most problematic case is Venezuela but trends are visible even in Ecuador, Brazil, Nicaragua and Mexico. These governments are characterized by reducing to mere formalism the procedures of control of the rule of law such as: division of powers, accountability mechanisism, transparency of public work. ${ }^{2}$ Populist governments often intervene in the judiciary and administrative courts, show disdain for institutions that gather information and evaluate the performance of government such as government account offices. These agencies, responsible for checks and balance to the executive branch often face attacks to their independance and pressures. As Kyle and Mounk's study of 36 populist governments in the 21 century shows there is $23 \%$ more probality that democratic institutions are damaged, and more than $50 \%$ of populist leaders reform constitutions to weaken executive checks and balances, more than $40 \%$ of populist challenge or disregard laws. ${ }^{3}$ Hence reducing democracy to its

\footnotetext{
${ }^{1}$ Dean of Master Program of Public Policy and Public Administration, Centro de Investigación y Docencia Económica (CIDE). ana.fierro@cide.edu

${ }^{2}$ Cesáreo Rodríguez Aguilera de Prat, La derecha iliberal frente al Estado de derecho, AGENDA_PúBLICA-EL PAIS (Sept. 27, 2019).

${ }^{3}$ Jordan Kyle \& Yascha Monk, The Populist Harm to Democracy AND EMPIRICAL AsSESSMent (2018).
} 
minimum by replacing institutions that protect the rule of law with the mobilization of people that grant unconditional support to a strong lider. ${ }^{4}$

Authors like Vergara ${ }^{5}$ and Mouffe $^{6}$ point out that the disillusion with democracies results form the fact that in modern states a large part of the population is marginalized from public decision-making. Only a minority with economic power succeed in influencing public decisions. While this criticism is attainable it is also true that accountability procedures, such as nulity and state liabilty trails are a powerful weapons for controlling public decisions in the hands of citizens. Modern society worked hard to achieve legal systems based on the rule of law and the promotion of human rights. These legal systems prevent citizens from being subject to the will of one leader. In our legal systems administrative courts play a fundamental role in controlling power and improving the performance of state bodies. These trails are a powerful weapon in the hands of all people. In fact, in the face of populism's advancement, having mechanisms to control the exercise of public powers and the use of public money, such as nullity and state liability trails becomes a powerful citizen's tool against arbitrariness and in favor of the rule of law. If disappointment with democracy comes from the lack of control of majorities over public decisions, access to administrative courts should be promoted as a means in the hands of everyone to bring government into account and control de abuse of power.

This paper explores the use of administrative courts as accountability mechanisms that protect the rule of law. Following Kitrosser, ${ }^{7}$ we understand accountability as the substantive dimension of the rule of law and part of the overall control of power by Congress and the judicial branch. We suggest that administrative courts are powerful procedures for government accountability and control against abuse of powers. We analyse nullity and state liability trails to show their use not only as tools for protecting the rule of law, but also for bringing the authorities to account and ordering measures for their improvement. We attempt to show the challenges these procedures still encounter to ensure access to justice and defence against abuse of power for everyone.

\footnotetext{
4 Vox Populi: Populismo y democracia de Latinoamérica 9-19 (Julio Aibar Gaete ed., 2007).

${ }^{5}$ Camila Vergara, Populism as Plebeian Politics: Inequality, Domination, and Popular Empowerment, 28 Journal OF Political Philosophy 222-46 (2020).

${ }^{6}$ Chantal Mouffe, La "fin du politique" et le défi du populisme de droite, RevuE Du MAUSs 178-194 (2002).

${ }^{7}$ H. KitrosSER, RECLAIMING ACCOUNTABILITY: TRANSPARENCY, EXECUTIVE POWER, AND THE U.S. CONSTITUTION (2018).
} 
In this paper we define accountability as a bilateral procedure between an agency obliged to inform and justify its actions to a court empowered to sanction them. ${ }^{8}$ Agencies are bound by the rule of law, but the legal system must have means to control their compliance. This guarantee is given by the administrative courts that review the legality and constitutionality of government actions making them accountable. Administrative courts serve as an oversight and accountability mechanism for decision-makers, these mechanisms ensure agencies follow appropriate processes and act according to their statutory mandates. They aim to boost public confidence and credibility of their decision-making, facilitate better and more consistent decisions, and reduce the risk of errors. They also promote fairness and justice, are means to prevent corruption, and provide opportunities to address wrongs through redress. ${ }^{9}$ Therefore, administrative courts are important controls of abuses of power. Populist seek to concentrate power by making decisions without due process, or exceeding the statutory limits, nullity and state liability trials can be used to stop them.

Professor Ginsburg points out that in the transition from authoritarian to democratic regimes controls of power shift from being predominantly ideological, and hierarchical, to institutionalized controls by accountability mechanisms. In democracies administrative courts become important accountability mechanisms of control of government actions. Hence administrative courts are often strengthened, as means where individuals denounce irregular actions that depart from the rule of law. This allows for the decentralization of control and empowers citizens to bring claims against government abuses. In this sense, individuals play an essential role in the defense of their rights as well as making agencies accountable for their actions. ${ }^{10}$ Populist government in contrast try to undermine this controls.

Administrative trails are forms of control through red flags activated by the public itself, who denounce decisions that do not adhere to legal or constitutional parameters. The claims brought in front of the court work as an alarm when government decisions are contrary to the rule of law. Moreover, the adversarial nature of trails brings to light elements that the agency would hardly reveal for itself. This information becomes public and may transcends to higher levels, including other branches such as the Legislative or the media. ${ }^{11}$ This achieves an

\footnotetext{
${ }^{8}$ ANA ELENA FIERRo FERRÁEs, Visión GENERAL dE LA RENDICIÓN DE CUENTAS DE AUTORIDADES ELECTAS EN EL ORDENAMIENTO JURÍDICO MEXICANO (2011).

${ }^{9}$ Lorne Sossine \& Hoffman Steven, The Elusive Search For Accountability: Evaluating Adjudicative Tribunals, 28 WINDSOR YEARBOOK OF ACCESS TO JusticE (2) 343-60, 2010.

${ }^{10}$ Tom Ginsburg, Administrative Law and the Judicial Control of Agents in Authoritarian Regimes, in RuLE BY LAw: THE Politics of Courts in Authoritarian Regimes 58-72 (Tom Ginsburg \& Tamir Moustafa eds, 2008).

${ }^{11} \mathrm{Id}$. at $58-72$.
} 
accountability procedure that does not depend on permanent ad hoc bodies, or general oversights. Also Nohlen ${ }^{12}$ considers there is a close relationship between democracy, accountability and the Constitution, on the one hand accountability is an element of democracy but, at the same time, the effectiveness of the means of control of constitutionality and the rule of law safeguards the supreme law of the land and the principle of democracy in it. Therefore, this accountability mechanism are important controls against the advancement of populist action that seek to weaken the rule of law.

Even though administrative trails are important defenses against abuses of power they are not always accessible to everybody. In some cases, the general public are not familiar with these procedures, in others legal counsel is expensive, the formalisms of the trail discourage people to bring claims. In this sense, especially in Latin America administrative courts are frequently use by the elites and less by vulnerable groups in society. States should broaden access to these mechanisms of accountability, by providing public defenders and making procedures more flexible. It is also important to educate people in their rights, and the ways the legal system provides them to defend them, as well as the importance of making government accountable for their decisions. Against the advancement of populist governments that threaten the rule of law people should have effective means to stop them, administrative trails are powerful arms for this purpose.

\section{REFERENCE LIST}

ANA ELENA FIERRO FERRÁES, VISIÓN GENERAL DE LA RENDICIÓN DE CUENTAS DE AUTORIDADES ELECTAS EN EL ORDENAMIENTO JURÍDICO MEXICANO (2011).

Camila Vergara, Populism as Plebeian Politics: Inequality, Domination, and Popular Empowerment, 28 Journal OF POLITICAL PhILOSOPHY 222-46 (2020). doi:10.1111/jopp.12203

Cesáreo Rodríguez Aguilera de Prat, La derecha iliberal frente al Estado de derecho, AGENDA_PÚBLICA-EL PAIS (Sept. 27, 2019), http://agendapublica.elpais.com/la-derechailiberal-frente-al-estado-de-derecho/

Chantal Mouffe, La "fin du politique" et le défi du populisme de droite, REVUE DU MAUSS 178-194 (2002).

H. KITROSSER, RECLAIMING ACCOUNTABILITY: TRANSPARENCY, EXECUTIVE POWER, AND THE U.S. CONSTITUTION (2018).

HÉCTOR FIX-FIERRO \& DiETER NOHLEN, LOS TRIBUNALES CONSTITUCIONALES EN LA CONSOLIDACIÓN DEMOCRÁtiCA. SuPREMA CORTE DE JuSTICIA DE LA NACIÓN (2008).

\footnotetext{
${ }^{12}$ Héctor FiX-Fierro \& Dieter Nohlen, Los tribunales CONSTITUCIONALES EN LA CONSOLIDACión DEMOCRÁTICA. SuPREMA CORTE DE JUSTICIA DE LA NACIÓN 43-103 (2008).
} 
JoRdAN Kyle \& YASCHA MONK, THE POPUlist HARM TO DEMOCRACY AND EMPIRICAL ASSESSMENT (2018), https://institute.global/insight/renewing-centre/populist-harmdemocracy

Lorne Sossine \& Hoffman Steven, The Elusive Search For Accountability: Evaluating Adjudicative Tribunals, 28 WiNDSOR YEARBOOK OF ACCESS TO JUSTICE (2) 343-60, 2010, http://www.uwindsor.ca/law/ljacobs/sites/uwindsor.ca.law.ljacobs/files/windsor_yearbook_a dmin_law_special_issue_2010_final.pdf

Tom Ginsburg, Administrative Law and the Judicial Control of Agents in Authoritarian Regimes, in RUle By LAW: THE POLITICS OF COURTS IN AUTHORITARIAN REGIMES 58-72 (Tom Ginsburg \& Tamir Moustafa eds, 2008). doi:10.1017/CBO9780511814822.003

Vox Populi: Populismo y DEMOCRACIA DE LATINOAMÉRICA 9-19 (Julio Aibar Gaete ed., 2007). 


\title{
EX-ANTE DEFERENCE AND REPARATIONS, THE CASE STUDIES OF COLOMBIA AND MEXICO
}

\author{
Adriana Garcia Garcia ${ }^{1}$ \\ Centro de Investigación y Docencia Económicas (CIDE), Mexico
}

\begin{abstract}
Usually analyses of deference consider courts' review of past agency action. Governments interpret in a specific manner a norm or regulation and the judge decides the lawfulness of that interpretation after the fact. However, judges analyze governments' future decisions as well, for example in granting reparations for human rights violations. Such decisions generally engage in an analysis of future actions that the government should perform in order to redeem victims and guarantee the violation will not recur. The underpinning principle of judicial deference is that a court should not attempt to second guess or substitute its judgment for the judgment of another decision maker, nor should it opine on the wisdom of a policy or law. With respect to human rights violations, a more deferential approach might let the government determine what measures it will take by way of reparations and prevention of recurrence, while a non-deferential approach would spell out such measures in detail. Examining cases in Colombia and Mexico issued during the past 10 years, in this paper I argue that domestic courts have been granting reparations in a less deferential manner over time. This trend is very clear when analyzing non-repetition measures granted in these countries which include attempts to oblige governments to issue laws, reduce sanctions, and prohibit the transit of specific streets.
\end{abstract}

Keywords: Deference, reparations, administrative justice.

Contents: 1. Introduction. 2. Deference. 3. Reparations. 4. Reparations in Colombia. 5. Reparations in Mexico. 6. Conclusions

\section{INTRODUCTION}

Usually analyses of deference consider courts' review of past agency action. Governments interpret in a specific manner a norm or regulation and the judge decides the lawfulness of that interpretation after the fact. However, judges analyze governments' future decisions as well, for example in granting reparations for human rights violations. Such

\footnotetext{
${ }^{1}$ Adriana Garcia Garcia is a professor at the Centro de Investigación y Docencia Económicas (CIDE) in Mexico and consultant at Open Society Justice Initiative. She holds a doctorate degree (JSD) from the University of Chicago Law School (2016), a juris doctor degree from the Autonomous Technological Institute of Mexico (Mexico), an LL.M. from the University of Chicago (2010) and a master in Law and Economics from the Complutense University (Spain). During her doctoral studies she was a visiting scholar at Columbia University (2012-2013). Her current research focuses on the study of reparations; state financial liability and administrative justice.
} 
decisions generally engage in an analysis of future actions that the government should perform in order to redeem victims and guarantee the violation will not recur. The underpinning principle of judicial deference is that a court should not attempt to second guess or substitute its judgment for the judgment of another decision maker, nor should it opine on the wisdom of a policy or law. The degree of deference will vary according to the levels of trust in the agency, the nature of the agency action, the enabling statute that provides the agency with power, and the specific issue in question. Through such considerations the court will determine how broad or narrow the scope of judicial review is in a certain case. With respect to human rights violations, a more deferential approach might let the government determine what measures it will take by way of reparations and prevention of recurrence, while a nondeferential approach would spell out such measures in detail.

International human rights standards oblige judges to issue reparations including measures of restitution, compensation, satisfaction, rehabilitation and non-repetition, but do not determine the appropriate level of deference, and international courts differ accordingly. While the European approach has tended towards a more deferential approach, the InterAmerican Court of Human Rights has been much less so. Examining cases in Colombia and Mexico issued during the past 10 years, in this paper I argue that the domestication of the InterAmerican human rights standards has led domestic courts to grant reparations in a less deferential manner over time. This trend is very clear when analyzing non-repetition measures granted in these countries which include attempts to oblige governments to issue laws, reduce sanctions, and prohibit the transit of specific streets.

In the first section I will address and explain the concept of deference as a characteristic of judges' attitudes towards governments. The second section will analyze the international standards of reparations, delving into the non-recurrence measures issued by the InterAmerican Court of Human Rights. The third section will be dedicated to the analysis of domestic decisions in Colombia and Mexico. The final section discusses the merits of the deferential approach vs. the non-deferential approach while granting reparations of human rights' violations in these countries.

\section{DEFERENCE}


As rightly noted by Anuradha Vaitheswaran and Thomas A. Mayes, a plain language definition of deference is respect or esteem for a superior ${ }^{2}$. For judicial deference, when a court is reviewing agency action, the judiciary "respects" the agency that is "superior" or elder. Hence, the underpinning principle of judicial deference is that a court should not attempt to second guess or substitute its judgment for the judgment of another decision maker, nor should it pass on the wisdom of a policy or law. ${ }^{3}$ Thus, deference consists of the method by which a court examines decisions made by the "bureaucratic state". 4

Three main justifications for the existence of deference are observed in the milestone case of Chevron v. Natural Resources Defense Council (1984): (i) agencies have greater political accountability than courts, (ii) agencies are often in a better position than the legislature to make difficult political choices, and (iii) agencies have greater expertise than courts and the legislature in administering often "technical and complex" regulatory schemes 5 .

Degrees of deference should be understood as degrees of respect toward agency action. If a court has more respect for the decisions of an agency, the deference used by the court to decide cases is greater. The three step analysis to establish the degree of deference include: to determine whether Congress has delegated authority to the agency to interpret the law; if it has, determine whether Congress has spoken directly about the particular issue; and if Congress has not spoken, assess whether the agency's interpretation is reasonable. These steps reflect the basic principles of judicial deference in the United States when assessing issues of law or mixed issues of law and fact. These principles have been outlined in three landmark cases, Chevron, Mead, and Skidmore. These cases have created a culture in which delegation in favor of the agency should be presumed where it is assumed (1) that the agency, rather than the reviewing court, is an expert on the statute in issue; (2) that resolving an ambiguity in a statute involves a policy judgment, which is more appropriately made by the agency than by a court; and (3)

\footnotetext{
${ }^{2}$ Anuradha Vaitheswaran \& Thomas A. Mayes, The Role of Deference in Judicial Review of Agency Action: A Comparison of Federal Law, Uniform State Acts, and the Iowa APA, 27 Journal of THE NATIONAL Association Of Administrative LAW JUDICIARY 402, 404 (2007).

${ }^{3}$ Daniel J. Solove, The Darkest Domain: Deference, Judicial Review, and the Bill of Rights, 84 Iowa Law ReVIEw 941, 943 (1999). The underlying principle of deference, as mentioned by Solove, is clearly reflected in Justice Holmes' famous dissent in Lochner in Lochner v. New York (1905): "I strongly believe that my agreement or disagreement has nothing to do with the right of a majority to embody their opinions in law."

${ }^{4}$ Daniel J. Solove, The Darkest Domain: Deference, Judicial Review, and the Bill of Rights, 84 Iowa Law Review 941, 943 (1999). The bureaucratic state is defined by Solove as "the web of interacting public and private institutions that regulate numerous facets of modern life."

${ }^{5}$ Melany D. Walker, Congressional Intent and Deference to Agency Interpretations of Regulations, 66 THE UNIVERSITY OF Chicago Law Review 1341, 1347 (1999).
} 
that the agency is authorized to make interpretations in a reasoned decision-making format (such as a legislative regulation) ${ }^{6}$.

\section{REPARATIONS}

Reparations are an indispensable element of fundamental international and national norms regarding human rights' violations cases. At the international level, every judgement finding a violation of human rights grants reparations to the victim. According to international norms and standards, reparations must be adequate, effective and comprehensive. ${ }^{7}$

Comprehensive reparation "means the re-establishment of the previous situation and the removal of the results which the violation produced"; 8 and considers, in addition to monetary compensation, the granting of other types of means of reparation such as restitution, rehabilitation, satisfaction and guarantees of non-repetition. ${ }^{9}$

Among these measures the one that covers the greater scope of government's powers is non-repetition measures. Non repetition measures may include issuing effective, clear instructions to public officials, strengthening the independence of the judiciary; establishing systems for regular and independent monitoring of all places of detention; providing, on a priority and continued basis, training for law enforcement officials as well as military and security forces on human rights law; reviewing and reforming laws; ensuring the availability of temporary services for individuals or groups of individuals, such as shelters for victims of gender-related or other torture or ill-treatment. ${ }^{10}$ While granting such types of measures has been applauded by victims' advocates it is clear that international judges attitudes towards governments cannot be described as deferential.

Reparations at the domestic level are also important elements of legal systems. At least 60 federal constitutions in the world spell out the right of victims of human rights abuses to obtain reparations. Among these, countries transitioning from an authoritative regime to a democratic one have increased the importance of the issue as reparations are seen as integral

\footnotetext{
${ }^{6}$ Chevron USA Inc. v. Natural Res. Def. Council Inc., 467 U.S. 837 (1984), 1175.

${ }^{7}$ UN Committee Against Torture (CAT), General comment no. 3, 2012: Convention against Torture and Other Cruel, Inhuman or Degrading Treatment or Punishment: implementation of article 14 by States parties (Dec. 13, 2012) paragraphs 2 and 6.

${ }^{8}$ Case of González et al. (“Cotton Field”) v. Mexico, IACtHR, Judgement of November 16, 2009, para. 450.

${ }^{9}$ Case of the Plan de Sánchez Massacre v. Guatemala, IACtHR, Judgement of April 29, 2004; Case of Rodríguez Vera et al. (The Disappeared from the Palace of Justice) v. Colombia, IACtHR, Judgement of November 14, 2014, Series C No. 287 , para. 543; Case of Herrera Espinoza et al. v. Ecuador, IACtHR, Judgement of September 1, 2016, Series C No. 316 , para. 214. ${ }^{10}$ UN Committee Against Torture (CAT), General comment no. 3, 2012: Convention against Torture and Other Cruel, Inhuman or Degrading Treatment or Punishment: implementation of article 14 by States parties (Dec. 13, 2012) paragraph 18.
} 
part of processes to address violations of the past. In recent years and as a result of the international influence, some countries have incorporated international standards regarding reparations into their own legal systems. As a result of the domestication of such standards, domestic judges have become less deferential towards government agencies when granting reparations. In this paper I will analyze two case studies: Colombia and Mexico. Each of these countries has issued interesting decisions obliging governments to issue laws, enact broad policies or void public policies.

\section{REPARATions in COLOMBia}

At a national level it can be observed that judges also use measures of non-repetition as part of reparations. Judges in Colombia, which has struggled with a long and brutal civil conflict and battles with drug gangs, developed sophisticated jurisprudence on reparations for abuses committed by state forces, including not only compensation but also rehabilitation to victims and the enactment of laws as non-recurrence measures.

For example, when the Constitutional Court of Colombia finds that various cases show systematic and continual violations of human rights, it issues a decision called the Unconstitutional State of Affairs where it underlines the structural causes of such violations and requires the government to take effective measures to remove the causes. ${ }^{11}$ The court has issued this type of decision in cases of displaced women and overcrowding in prisons. ${ }^{12}$

Similarly, the Constitutional Court of Colombia has established that: "The guarantee of non-repetition is composed of all the actions aimed at preventing behavior from re-occurring which impacted on the rights of the victims and which must be appropriate to the nature and magnitude of the offence. The guarantee of non-repetition is directly related to the obligation of the State to prevent gross violations of human rights; this includes the adoption of measures of a legal, political, administrative and cultural nature that promote safeguarding rights. In particular, the following contents of this obligation have been identified: (i) recognize the rights at an international level and offer guarantees of equality; (ii) draw up and implement strategies and policies of comprehensive prevention; (iii) implement programs of education and dissemination aimed at eliminating patterns of violence and infringement of rights and inform people of rights, mechanisms of protection and the consequences of their infringement; (iv) introduce programs and promote practices that allow an effective response to complaints of

\footnotetext{
${ }^{11}$ Judgement T-025/2004, Constitutional Court of Colombia, of January 22, 2004.

12 Judgement T-388/2013, Constitutional Court of Colombia, of June 28, 2013.
} 
human rights violations as well as strengthen institutions with functions in that field; (v) assign sufficient resources to support prevention efforts; (vi) adopt measures to eradicate risk factors; this includes devising and implementing instruments to facilitate the identification and notification of factors and events that pose the risk of violation; (vii) take specific prevention measures in cases where a group of people is found to be at the risk of their rights being violated."13

In turn, the Council of State of Colombia has played an active role in granting measures of non-repetition. In its jurisprudence it has reiterated that: "In order to specify the preventive role which jurisprudence must have on administrative disputes... in cases of gross violations of human rights (...) it is of great importance for the Council of State to highlight, in cases such as the present one, the inappropriate behavior committed by state agents, with the aim of setting a precedent which obliges the public administration to pull out by the root this type of behavior and for the case to receive due reparation which would make the recurrent recourse of citizens to international organizations unnecessary." 14

\section{REPARATIONS IN MeXico}

Non- repetition guarantees are perhaps one of the most explored concepts, in terms of reparations, by the Supreme Court of Mexico. Article 27 of the Mexican General Law on Victims defines non-repetition guarantees as measures to ensure that the acts resulting in a human rights violation will not happen again. The Court, whenever addressing a human rights violation issue and the reparations that must emanate from it, has been clear about the necessity of implementing public policies that would guarantee an environment respectful of human rights, through institutional, social and cultural change. For example:

In Amparo 476/2014, the Supreme Court established that non-monetary reparations, also known as moral reparations, are classified as: a) restitution and rehabilitation, b) satisfaction, and c) guarantees of non-repetition. Guarantees of non-repetition are intended to ensure that the State's harmful actions are never to be repeated and they consist on public policies aimed to influence social, legal and political institutions ${ }^{15}$

In Amparo 476/2014 the Supreme Court established the State's obligation to investigate, punish and remedy human rights violations entails the execution of everything

\footnotetext{
${ }^{13}$ Judgement T-418/15, Constitutional Court of Colombia, of July 3, 2015.

${ }^{14}$ Case of Sapuyes Argote et al., Section III, Subsection B, Council of State of Colombia, Judgement of April 30, 2014, Loc. 28075.

${ }^{15} \mathrm{Ibid}$.
} 
necessary to achieve its restoration. Therefore, human rights immediate observance can be demanded through comprehensive reparations or it could result in progressive actions. In the latter sense, the solution adopted by the State should serve not only to particular interest but also to the purpose of restructuring political and social environment that is respectful of human rights. In other words, reparations are about thinking about a particular case but also to promote actions that can serve as guidelines for future governmental activities. ${ }^{16}$

As established by the Supreme Court, in Mexico, lower and administrative courts have notably ordered state institutions to publicly acknowledge their responsibility for human rights violations - such as the public apology delivered by the federal prosecutor in February, 2017, to three indigenous women who had spent three years in prison on fabricated charges. ${ }^{17}$ Mexico's eventual decision in December, 2018, to create a commission of inquiry into the disappearance of 43 students in the infamous 2014 Ayotzinapa case was also informed by a court order. Other measures ordered in Mexico have included requiring city authorities to list streets deemed unsafe for unaccompanied women, and requiring the publication by the executive branch of Gender Violence Alerts in the State of Mexico in 2018.

\section{Conclusions}

Beyond the restorative function of reparations, if properly designed, reparations can generate the correct incentives to minimize illegal actions of government in the future. Measures of reparations impose costs on government actions. In fact, recent reviews of the deterrence literature from domestic legal systems conclude that there is much firmer evidence for a substantial deterrent effect than there was two decades ago. ${ }^{18}$

Reparations are undoubtedly related to the issue of preventing impunity. ${ }^{19}$ Therefore, judges should consider not only the specific circumstances of the individual case, but also the deterrent effects of the decision for future violations. In this regard, the analysis of reparations functions is concerned not only with the individual case but also with how reparations affect

\footnotetext{
${ }^{16} \mathrm{Ibid}$.

${ }^{17}$ Adriana Garcia \& Mercedes Melon, How Mexican Human Rights Lawyers Found a New Route to Accountability, OPEN SOCIETY FoundATIONS (Feb. 21, 2017).

${ }^{18}$ Daniel S. Nagin, Criminal Deterrence Research at the Outset of the Twenty-First Century, in CRIME AND JusTICE: A REVIEW of RESEARCH 1-42 (M. Tonry ed., 1998).

${ }^{19}$ Theo Van Boven, The United Nations Basic Principles and Guidelines on the Right to a Remedy and Reparation for Victims of Gross Violations of International Human Rights Law and Serious Violations of International Humanitarian Law, UNITED NATIONS AUdiovisuAl LibRARY OF INTERNATIONAL LAW, 2010.
} 
other actors' future behavior and judges cannot analyze the latter without engaging in a nondeferential approach. ${ }^{20}$

While the deference literature focuses on the benefits of allowing expert agencies to issue decisions and specific measures, the human Rights' debate on reparations makes clear that when analyzing Human Rights violations issues it is more important to ensure the respect to Human Rights rather than the respect to agencies' expertise.

\section{REFERENCE LIST}

Adriana Garcia \& Dirk Zavala Rubach, The Judicial Power and the Human Rights' Amendment. A Game Theory Analysis", in The Constitutional AMENDMENT On Human RIGHTS: THE COST OF ITS IMPLEMENTATION 23-48 (2014).

Adriana Garcia \& Mercedes Melon, How Mexican Human Rights Lawyers Found a New Route to Accountability, OPEN SOCIETY FOUNDATIONS (Feb. 21, 2017), https://www.opensocietyfoundations.org/voices/how-mexican-human-rights-lawyers-foundnew-route-accountability

Anuradha Vaitheswaran \& Thomas A. Mayes. The Role of Deference in Judicial Review of Agency Action: A Comparison of Federal Law, Uniform State Acts, and the Iowa APA, 27 Journal of the NATIONAL Association OF ADMINISTRATIVE LAW JUdiCIARY 402-46 (2007).

Case of González et al. ("Cotton Field") v. Mexico, IACtHR, Judgement of November 16, 2009.

Case of Herrera Espinoza et al. v. Ecuador, IACtHR, Judgement of September 1, 2016, Series C No. 316, para. 214.

Case of Rodríguez Vera et al. (The Disappeared from the Palace of Justice) v. Colombia, IACtHR, Judgement of November 14, 2014, Series C No. 287.

Case of Sapuyes Argote et al., Section III, Subsection B, Council of State of Colombia, Judgement of April 30, 2014, Loc. 28075.

Case of the Plan de Sánchez Massacre v. Guatemala, IACtHR, Judgement of April 29, 2004.

Chevron USA Inc. v. Natural Res. Def. Council Inc., 467 U.S. 837 (1984).

Daniel J. Solove, The Darkest Domain: Deference, Judicial Review, and the Bill of Rights, 84 IOWA LAW REVIEW 941-1023 (1999).

Daniel S. Nagin, Criminal Deterrence Research at the Outset of the Twenty-First Century, in 21 CRime AND Justice: A REVIEW OF RESEARCH 1-42 (M. Tonry ed., 1998).

Judgement T-025/2004, Constitutional Court of Colombia, of January 22, 2004.

Judgement T-388/2013, Constitutional Court of Colombia, of June 28, 2013.

Judgement T-418/15, Constitutional Court of Colombia, of July 3, 2015.

${ }^{20}$ See Adriana Garcia \& Dirk Zavala Rubach, The Judicial Power and the Human Rights' Amendment. A Game Theory Analysis, in The Constitutional Amendment on Human Rights: The Cost of its Implementation 23-48 (2014). 
Melany D. Walker, Congressional Intent and Deference to Agency Interpretations of Regulations, 66 THE UnIVERSITY OF CHICAGO LAW REVIEW 1341-71 (1999).

Theo Van Boven, The United Nations Basic Principles and Guidelines on the Right to a Remedy and Reparation for Victims of Gross Violations of International Human Rights Law and Serious Violations of International Humanitarian Law, UNITED NATIONS AUDIOVISUAL LIBRARY OF INTERNATIONAL LAW (2010).

UN Committee Against Torture (CAT), General comment no. 3, 2012: Convention against Torture and Other Cruel, Inhuman or Degrading Treatment or Punishment: implementation of article 14 by States parties (Dec. 12, 2012). 


\title{
ADMINISTRATIVE DEFERENCE AND ITS LINK WITH THE NON-DELEGATION DOCTRINE IN THE LAW OF THE UNITED STATES
}

\author{
Ilaria Di Gioia ${ }^{1}$ \\ Birmingham City University, UK
}

\begin{abstract}
This essay is an exploration of the theoretical origins of administrative deference in the Unites States. It argues that the doctrine of administrative deference finds its theoretical justification in the increasing delegation of the power to execute statutes from Congress to the Executive. It discusses the cases of Chevron and Mead as key cases for the evolution of the delegation doctrine and concludes with the recent treatment of the doctrine in the case of Gundy.
\end{abstract}

Keywords: non, delegation doctrine, administrative deference, Chevron.

Contents: 1 . Introduction. 2. From "non-delegation" to "delegation" doctrine. 3. Chevron and Mead: deference to administrative agencies' interpretation of statutes. 4. No movement (yet) on the non-delegation doctrine: Gundy v. United States (2019).

\section{INTRODUCTION}

The question of whether courts should defer interpretation of ambiguous provisions to agencies is often regarded as a technical question relevant to some aspect of administrative law procedure. In reality, far from being only a technicality, it is a question that encompasses legal issues related to the doctrine of separation of powers and the broader constitutionality of congressional delegation of powers to administrative agencies.

This extended abstract explores the theoretical link between the non-delegation doctrine and the practice of administrative deference. More broadly, it examines the argument that the delegation of power to interpret laws and regulations is an implicit consequence of the delegation of power to execute congressional statutes and issue regulations.

\section{FROM "NON-DELEGATION" TO "DELEGATION" DOCTRINE}

\footnotetext{
${ }^{1}$ Associate Director of the Centre for American Legal Studies, Birmingham City University. Ilaria.DI-GIOIA@bcu.ac.uk
} 
The American Constitution attributes the legislative power to Congress (Art. I), the executive power to the President (Art. II) and the "judicial power" to the courts (Art. III) but it is silent on agency powers. The provisions related to the executive power mainly concern the President and "officers of the United States who are commissioned by the president." 2 Such an omission sits uncomfortably with the recent growth of the administrative state and the consequent increase of the power of agencies that constitute, according to some, a fourth branch of government. ${ }^{3}$ It is a fact that administrative agencies have executive, legislative, and judicial functions. They perform executive functions through agency enforcement, legislative functions through rulemaking and judicial functions through administrative hearings and administrative deference. Even though their role had not been explicitly acknowledged in the text of the Constitution, 4 administrative agencies de facto perform the actions above on delegation of Congress.

Hence, a question is in order: how have the courts justified the delegation of legislative, executive and interpretive power to administrative agencies? The answer is controversial and resides in the modern recognition of the impracticability of a strict application of the traditional non-delegation doctrine. This is the legal doctrine according to which Congress, vested with "all legislative powers" by Article I of the Constitution, cannot delegate these powers to another branch. $^{5}$

With the growth of the administrative state, the courts started to take distance from the traditional understanding of the principle of separation of powers and recognized that overlaps and delegations were necessary for the functioning of the modern state.

\footnotetext{
${ }^{2}$ U.S. CONST. art. II, $\S 3$.

${ }^{3}$ Peter L. Strauss, The Place of Agencies in Government: Separation of Powers and the Fourth Branch, 84 COLUM. L. REV. 573, 576-77 (1984). For an early reflection on the role of agencies see Justice Jackson's dissenting opinion in FederalTrade Commission v. Ruberoid Co., 343 U.S. 470, 487 (1952): "The rise of administrative bodies probably has been the most significant legal trend of the last century and perhaps more values today are affected by their decisions than by those of all the courts, review of administrative decisions apart. They also have begun to have important consequences on personal rights. Cf. United States v. Spector, 343 U.S. 169, 72 S.Ct. 591. They have become a veritable fourth branch of the Government, which has deranged our three-branch legal theories much as the concept of a fourth dimension unsettles our three-dimensional thinking."

${ }^{4}$ David A. Strauss, The Living Constitution (2010) at 122 (stating that "[ $t$ the New Deal is famous for having greatly increased the number of ... agencies" that combined "executive, legislative, and judicial functions").

${ }^{5}$ Notably, the non-delegation doctrine finds deep roots in John Locke's social contract theory: "[t]he power of the legislative, being derived from the people by a positive voluntary grant ..., can be no other than what the positive grant conveyed, which being only to make laws, and not to make legislators". John Locke, Second Treatise on Civil Government $\S \S 141$ (1690). The Supreme Court discussed this principle in numerous instances. See for example Mistretta v. United States, 488 U.S. 361,371 (1989) ("The nondelegation doctrine is rooted in the principle of separation of powers."). See also two early cases: Marshall Field \& Co. v. Clark, 143 U.S. 649, 692 (1892) (That congress cannot delegate legislative power to the president is a principle universally recognized as vital to the integrity and maintenance of the system of government ordained by the constitution.) and Field v. Clark, 143 U.S. 649, 692 (1892).
} 
This essay argues that the result of this development in the jurisprudence and in the law is that the non-delegation doctrine has been weakened to the point of becoming a de facto delegation doctrine that in turn provided the theoretical foundations for the development of the administrative state and -as a consequence- also for the judicial practice of administrative deference, intended here as the delegation of interpretive power to agencies over statutes that they administer or regulations that they issue. The assumption is that if Congress is allowed to delegate lawmaking authority to administrative agencies by providing guidance in the form of intelligible principles, then Congress can also delegate interpretive power over ambiguous statutes administered by the agencies (Chevron deference) or the agencies own regulations (Auer deference). The next section discusses the doctrine of administrative deference as developed by the courts.

\section{ChEVRon ANd Mead: Deference to Administrative AgenCies INTERPRETATION OF STATUTES}

The seminal case concerning administrative deference in the United States is the Chevron case, ${ }^{6}$ a 1984 Supreme Court decision that has become the most cited case in federal administrative law. ${ }^{7}$

In this case the Court suggested that the theoretical basis for administrative deference is the assumption that when Congress delegates implementation to an agency, it also implicitly delegates interpretive authority i.e. the authority to make policy decisions. Justice Stevens delivered the opinion of the Court; he explained judicial deference as a two-steps process; the first step involves an assessment as to whether Congress has already spoken to the precise question at issue. The second step -reached only if Congress did not speak clearly on the issueis to question whether the administrative agency's interpretation is reasonable.

The different extent to which courts should accord Chevron deference was elaborated further by Justice Souter (joined by Rehnquist, C.J., Stevens, O' Connor, Kennedy, Thomas, Ginsburg, and G. Breyer) in United States v. Mead Corp. (2001). ${ }^{8}$

The issue at stake was weather ruling letters issued by the United States Customs Service to classify and fix the rate of duty on imports should be accorded judicial deference.

\footnotetext{
${ }^{6} 467$ U.S. 837 (1984).

${ }^{7}$ See Thomas W. Merrill, Justice Stevens and the Chevron Puzzle, 106 Nw. U. L. REv. 551, 551-53 (2012).

${ }^{8} 533$ U.S. 218 (2001). Mead held that when agencies acted with the "force of law," the Court should accord them Chevron deference.
} 
Justice Souter clarified that Chevron can be applied only to agency regulations that hold the "force of law" i.e. those regulations that have been preceded by the notice and comment as under the Administrative Procedure Act (APA). The ruling letters did not fall under this definition and could only be accorded Skidmore deference.

More importantly, for the purpose of examining the theoretical foundation of deference, is that the decision added a step zero to the two steps devised by Chevron. According to Mead, before proceeding to step one, a court must inquire whether there was congressional intent to delegate to the agency i.e. establish that "Congress delegated authority to the agency generally to make rules carrying the force of law, and that the agency interpretation claiming deference was promulgated in the exercise of that authority." 10

By creating a step 0, Mead formally recognised that when Congress delegates the authority to implement a particular provision, it may also choose to delegate interpretive authority on the same provision. In the words of the then Harvard Professor Elena Kagan, Mead represented "the apotheosis of a developing trend in Chevron cases" that treated Chevron "as a congressional choice, rather than either a constitutional mandate or a judicial doctrine". ${ }^{11}$

Administrative deference is, according to Mead and its progeny, "a judicial construction" 12 or a "fictionalized statement of legislative desire" ${ }^{13}$ that nonetheless reflects the needs of the contemporary administrative state.

If Chevron constituted a pillar of administrative law, the Mead development makes it a constitutional law seminal case with deep roots in theoretical constitutional discourse.

It is not surprising that, for its relevance in the U.S. Constitutional dynamics, it has been at the center of heated debates on the proper allocation of interpretive power and defined by Prof. Sunstein "a kind of counter-Marbury for the administrative state"14 and "the administrative state's very own McCulloch v. Maryland.”15

Mead represents the explanation of the theoretical foundation of administrative deference and this essay argues that its 'step 0 ' is the connecting ring between the nondelegation doctrine and administrative deference.

\footnotetext{
${ }^{9}$ United States v. Mead Corp., 533 U.S. 218, 221 (2001): "We agree that a tariff classification has no claim to judicial deference under Chevron, there being no indication that Congress intended such a ruling to carry the force of law, but we hold that under Skidmore v. Swift \& Co., 323 U.S. 134, 65 S.Ct. 161, 89 L.Ed. 124 (1944), the ruling is eligible to claim respect according to its persuasiveness."

${ }^{10} \mathrm{Id}$. at 226-27.

${ }^{11}$ David J. Barron \& Elena Kagan, Chevron's Nondelegation Doctrine, 2001 SuP. CT. REv. 201, 212 (2001).

${ }^{12} \mathrm{Id}$.

${ }^{13} \mathrm{Id}$.

${ }^{14}$ Cass R. Sunstein, Beyond Marbury: The Executive's Power to Say What the Law Is, 115 YALE L.J. 2580, 2589 (2006).

${ }^{15}$ Cass R. Sunstein, Chevron Step Zero, 92 VA. L. Rev. 187, 190 (2006).
} 
This theoretical assumption has not been free of criticism both from academic circles and court benches. Chevron has been subject to criticism and controversies over what commentators called the 'legal fiction' at the basis of the decision i.e. the presumption that Congress could constitutionally delegate legislative powers to regulatory agencies controlled by the President. ${ }^{16}$

One of the scholarly arguments against Chevron/Mead is that the doctrine is not consistent with Section 706 of the APA which establishes that courts are tasked with the review of agency action and they "shall ... interpret ... statutory provisions." 17 The argument is that the APA does not assign any role in statutory interpretation to agencies ${ }^{18}$ and is therefore to be interpreted as an instruction to courts to use traditional canons of interpretation. ${ }^{19}$

On the constitutional side of the dispute, scholars and judges alike have criticized Chevron/ Mead for incompatibility with Art. I and Art. III.

Justice Thomas expressed discomfort with deference to agencies in Michigan v. EPA (2015), ${ }^{20}$ where he argued that Chevron delegation "is in tension with Article III's Vesting Clause, which vests the judicial power exclusively in Article III courts, not administrative agencies" ${ }^{21}$ and in tension with Art. I "which vests '[a]ll legislative Powers herein granted' in Congress" thus advancing the case for revision of the doctrine.

Another fierce critic of the delegation doctrine and its consequences on administrative deference is Justice Gorsuch who, during his tenure as Appeal Judge, asserted that the doctrine is not only "seemingly at odds with the separation of legislative and executive functions" 22 but also creates concerns related to due process (fair notice) and equal protection that only magistrates "muster." 23

\footnotetext{
${ }^{16}$ The controversy is mainly related to the scope of legislative power of Congress as established by art. 1 of the Constitution. 175 U.S.C. $\$ 706$ (2012): "To the extent necessary to decision and when presented, the reviewing court shall decide all relevant questions of law, interpret constitutional and statutory provisions, and determine the meaning or applicability of the terms of an agency action.".

18 See Patrick J. Smith, Chevron's Conflict with the Administrative Procedure Act, 32 VA. TAx Rev. 813, 818 (2013) (It is impossible to reconcile the requirement in section 706 of the APA that "the reviewing court shall ... interpret ... statutory provisions" with Chevron's holding that, under step two, a reviewing court must accept an agency's "permissible construction of the statute" even if the agency interpretation is not "the reading the court would have reached if the question initially had arisen in a judicial proceeding). See also John F. Duffy, Administrative Common Law in Judicial Review, 77 Tex. L. REv. 113, 193-99 (1988).

${ }^{19}$ Aditya Bamzai, The Origins of Judicial Deference to Executive Interpretation, 126 YALE L.J. 908, 976-95 (2017): “section 706 is best interpreted as an attempt to ... instruct courts to review legal questions using independent judgment and the canons of construction".

${ }^{20}$ Michigan v. E.P.A., 135 S. Ct. 2699 (2015).

${ }^{21} \mathrm{Id}$. at 2712-14.

${ }^{22}$ Gutierrez-Brizuela v. Lynch, 834 F.3d 1142, 1154 (10th Cir. 2016).

${ }^{23} \mathrm{Id}$. at 1152.
} 


\section{No Movement (YET) ON THE NON-DELEgation DoCTRINE: GUNDY V. UNITED STATES (2019)}

In June 2019, the Supreme Court considered a non-delegation challenge and, despite Federalist Society's rumors that the time was ripe for a U-turn on the non-delegation doctrine, ${ }^{24}$ the court confirmed that the post-1935 evolution of the non-delegation doctrine into a delegation doctrine was not to be reversed. The case involved the constitutionality of 34 U.S.C. $\S 20913$ (d), a provision of the Sex Offender Registration and Notification Act (SORNA) that delegates power to the Attorney General "to specify the applicability" of the registration requirements to offenders convicted before the statute's enactment. ${ }^{25}$ The court, in a plurality opinion by Justice Kagan, Ginsburg, Breyer and Sotomayor, held such delegation constitutional. Justice Kagan cited to precedents such as Mistretta ${ }^{26}$ and Hampton ${ }^{27}$ and reiterated that the Constitution allows Congress to delegate discretion as long as Congress provides an intelligible principle to direct the actions of the delegee. She hold that "Congress is on the need to give discretion to executive officials to implement its programs" 28 and therefore argued that delegation is a constitutional necessity that the Court has recognised from a long time. ${ }^{29}$

Justice Alito filed a concurring opinion in which he agreed with Justice Kagan that the post-1935 rejection of non-delegation arguments directed the court to reject this challenge but that he would be open to reconsider this approach if there was a majority. ${ }^{30}$

On the other side of spectrum, Justice Gorsuch filed a 33 pages dissent joined by Chief Justice Roberts and Justice Thomas. His dissenting opinion is, as expected, full of originalist verve. The reader gets the impression that Justice Gorsuch is preparing the ground for a future overhaul of the non-delegation doctrine when he appeals to the intent of the framers to confer

\footnotetext{
${ }^{24}$ See Matthew Cavedon \& Jonathan Skrmetti, Party Like It's 1935?: Gundy v. United States and the Future of the NonDelegation Doctrine, 19 FedERALIST SOC' REV. 42 (2018).

2534 U.S.C.A. $§ 20913$ (D), “The Attorney General shall have the authority to specify the applicability of the requirements of this subchapter to sex offenders convicted before the enactment of this chapter ... and to prescribe rules for the registration of any such sex offenders and for other categories of sex offenders who are unable to comply with subsection (b)."

${ }^{26}$ Mistretta v. United States, 488 U.S. 361 (1989).

${ }^{27}$ J. W. Hampton, Jr., \& Co. v. United States, 276 U.S. 394 (1928).

${ }^{28}$ Gundy v. United States, 139 S. Ct. 2116, 2130 (2019).

${ }^{29} \mathrm{Id}$. ("Consider again this Court's long-time recognition: 'Congress simply cannot do its job absent an ability to delegate power under broad general directives.' Mistretta, 488 U.S. at 372, 109 S.Ct. 647”).

${ }^{30} I d$. at 2131 ("If a majority of this Court were willing to reconsider the approach we have taken for the past 84 years, I would support that effort. But because a majority is not willing to do that, it would be freakish to single out the provision at issue here for special treatment").
} 
sovereignty to the people and insists that delegation of legislative power to the executive frustrates "the system of government ordained by the Constitution." "31

His specific argument is that the delegation of power to specify applicability of the registration requirement constitutes the delegation of unfettered discretion to decide which requirements to impose on which pre-Act offenders and therefore to determine offenders' rights, something that the executive cannot do. ${ }^{32}$

Justice Kavanaugh took no part in the consideration or decision of Gundy because he was not a member of the court when the case was argued in October 2018. However, doubts remain as to what the decision would have been if Kavanaugh had been part of the court and a whether the non-delegation doctrine could stand a future challenge in this conservative-leaning court. Mila Sohoni, commenting on the case on ScotusBlog, rightly contended that "the significance of Gundy lies not in what the Supreme Court did today, but in what the dissent and the concurrence portend for tomorrow." 33

In conclusion, administrative deference remains in the spotlight and its foundations are in peril in the United States. It has resisted a first attack, but this does not provide assurance that it will resist future challenges.

\footnotetext{
${ }^{31} I d$. at 2133 ("The framers understood, too, that it would frustrate "the system of government ordained by the Constitution" if Congress could merely announce vague aspirations and then assign others the responsibility of adopting legislation to realize its goals.19 Through the Constitution, after all, the people had vested the power to prescribe rules limiting their liberties in Congress alone. No one, not even Congress, had the right to alter that arrangement.").

${ }^{32}$ Gundy v. United States, 139 S. Ct. 2116, 2143 (2019).

${ }^{33}$ Mila Sohoni, Opinion analysis: Court refuses to resurrect nondelegation doctrine, ScotusBLOG (June 20, 2019).
} 


\section{LIST OF ABBREVIATIONS}

APA - Administrative Procedure Act

EPA - Environmental Protection Agency

SORNA - Sex Offender Registration and Notification Act

\section{REFERENCE LIST}

34 U.S.C.A. § 20913 (d).

467 U.S. 837 (1984).

5 U.S.C. $§ 706$ (2012).

533 U.S. 218 (2001).

Aditya Bamzai, The Origins of Judicial Deference to Executive Interpretation, 126 YALE L.J. 908-1001 (2017).

Cass R. Sunstein, Beyond Marbury: The Executive's Power to Say What the Law Is, 115 YALE L.J. 2580-2610 (2006).

Cass R. Sunstein, Chevron Step Zero, 92 VA. L. REv. 187-249 (2006).

David A. StRauss, The Living Constitution (2010).

David J. Barron \& Elena Kagan. Chevron's Nondelegation Doctrine, 2001 SuP. CT. REV. 201265 (2001).

Fed. Trade Comm'n v. Ruberoid Co., 343 U.S. 470, 487 (1952).

Field v. Clark, 143 U.S. 649, 692 (1892).

Gundy v. United States, 139 S. Ct. 2116, 2130 (2019).

Gundy v. United States, 139 S. Ct. 2116, 2143 (2019).

Gutierrez-Brizuela v. Lynch, 834 F.3d 1142, 1154 (10th Cir. 2016).

J. W. Hampton, Jr., \& Co. v. United States, 276 U.S. 394(1928).

John F. Duffy, Administrative Common Law in Judicial Review, 77 TEX. L. REV. 113 (1988). John Locke, Second Treatise on Civil Government (1690).

Marshall Field \& Co. v. Clark, 143 U.S. 649, 692 (1892).

Matthew Cavedon \& Jonathan Skrmetti, Party Like It's 1935?: Gundy v. United States and the Future of the Non-Delegation Doctrine, 19 FEDERALIST SoC' REV. $42-53$ (2018).

Michigan v. E.P.A., 135 S. Ct. 2699, (2015).

Mila Sohoni, Opinion analysis: Court Refuses To Resurrect Nondelegation doctrine, SCOTUSBLOG (June 20, 2019), https://www.scotusblog.com/2019/06/opinion-analysis-courtrefuses-to-resurrect-nondelegation-doctrine/

Mistretta v. United States, 488 U.S. 361 (1989). 
Patrick J. Smith, Chevron's Conflict with the Administrative Procedure Act, 32 VA. TAX REV. 813-40 (2013).

Peter L. Strauss, The Place of Agencies in Government: Separation of Powers and the Fourth Branch, 84 CoLum. L. REV. 573-669 (1984).

Skidmore v. Swift \& Co., 323 U.S. 134, 65 S.Ct. 161, 89 L.Ed. 124 (1944).

Thomas W. Merrill, Justice Stevens and the Chevron Puzzle, 106 Nw. U. L. REV. 551-66 (2012).

U.S. CONST.

United States v. Mead Corp., 533 U.S. 218, 221 (2001).

United States v. Spector, 343 U.S. 169, 72 S.Ct. 591. 


\title{
HOW THE PANDEMIC MIGHT BOOST REDISCOVERING JUDICIAL DEFERENCE TO ADMINISTRATIVE CHOICES AS A POSSIBILITY
}

\author{
Vanice Regina Lirio do Valle ${ }^{1}$ \\ Procuradoria Geral do Município do Rio de Janeiro, Brazil
}

\begin{abstract}
This paper presents initial signs of a new sensibility in the Brazilian Constitutional Court in reassessing the deferential approach when it comes to judicial review over public choices held by the administrative state. Precedents can be presented before the pandemics, and event after, in provisional injunctions held by the Court, considering a normative framework edited to address the health crisis that expanded the deliberative powers of federative entities and administrative agencies. Even though the limited number of rulings prevent classifying those events as a new trend in the Brazilian Constitutional Court, peremptory refusal on the deferential approach is certainly overcome.
\end{abstract}

Keywords: Judicial deference, public choices, judicial control over the administrative state, pandemics.

Contents: 1 . Preliminary considerations. 2 . Reassessing the deferential approach: initial signs before the pandemic. 3. Pandemics and the reaffirmation of the judicial deferential approach. 4 Can we proclaim a new trend in the Court's usage of the deferential approach?

\section{Preliminary CONSIDERATions}

A strong and independent Judiciary, leaded by the Brazilian Supreme Federal Court, is an undisputed and celebrated feature of the Brazilian 1988 Constitution. ${ }^{2}$ History explains how progressive forces in the National Constituent Assembly sponsored the idea that the institutional design should provide independent instances in which people could seek due protection for a wide range of human rights granted in the constitution.

Judicial independence associated with another constitutional clause granting "access to justice" lead to intense judicialization in almost every aspect of life. Aside from the worldwide

\footnotetext{
${ }^{1}$ Visiting Fellow at the Human Rights Program - Harvard Law School, Doctorate at Gama Filho University. Public lawyer, providing legal representation and legal consulting to Rio de Janeiro's City Hall, and currently directs the Research Center in "Procuradoria Geral do Município do Rio de Janeiro". E-mail: vanicevalle@gmail.com

${ }^{2}$ Luís Roberto Barroso et al., Developments in Brazilian constitutional law: The year 2016 in review, 15 INTERNATIONAL JOURNAL OF CONSTITUTIONAL LAW 496-497 (2017).
} 
phenomena known as judicialization of politics, ${ }^{3}$ according to the "Justice in Numbers Report", issued by the National Council of Justice, ${ }^{4}$ in 2019 there were 78,7 million pending lawsuits in Brazil. That huge number was celebrated as a decrease considering 2018, when there were 80 million pending cases.

A significant part of those lawsuits involves the Public Administration in two distinct types of dispute: tax law and human rights protection. ${ }^{5}$ Historically, in both subjects, the deferential approach has not been very prestigious, usually understood by judges as an undesired limitation to judicial scrutiny. According to that view, judicial control over public policies related to human rights promotion should not depart from a deferential approach. Extremists even proclaim that resource limitations, strategical prioritization defined by distributive concerns and similar issues should not be considered as limitation to judicial control over administrative choices.

Despite the seductiveness of such a proclamation, it enables the issuing of rulings that deeply affect executive planning and regulation. Such rulings, well-intended as they might be, can bring about inequality among plaintiffs (different judges interpreting the same executive choice in different ways); they can also suffer from ineffectiveness, when built on a misunderstanding of a certain issue or departing from a misunderstanding about the resources actually available to face it. A final risk relates to undetected correlations between the administrative strategy under scrutiny, and other public policies. In that scenery, striking the former can negatively affect the latter, causing an unpredictable ripple effect.

These side effects, and the distortions they can bring to the whole public health system in Brazil should not be minimized. Designed by the Brazilian constitution as a national e unified system, the "SUS" (abbreviation for 'unified health system') encompasses all the federative level in a single structure providing services to $80 \%$ of the population, with more than 150 million citizens insured. Redesigning any strategy in such a huge structure can easily affect hundreds of thousands of Brazilians ${ }^{6}$ - and even foreigners in the national territory, who are also insured by this same public health system.

\footnotetext{
${ }^{3}$ Rogério B. Arantes, Constitutionalism, the Expansion of Justice and the Judicialization of Politics in Brazil, in THE JUDICIALIZATION OF POLITICS IN LATIN AMERICA 231-62 (Rachel Sieder; Line Schjolden \& Alan Angell eds, 2005).

${ }^{4}$ Conselho Nacional de JustiçA, JustiçA em Números 2019 (2019).

${ }^{5}$ Estefania Maria de Queiroz Barboza \& Katya Kozicki, Judicalization of Politics and the Judicial Review of Public Policies by the Brazilian Supreme Court, 13 DiRITTO \& QUESTIONI PUBBLICHE 407-44 (2013).

${ }^{6}$ Daniel Wl Wang, Courts and health care rationing: the case of the Brazilian Federal Supreme Court, 8 HeALTH ECONOMICS, POLICY AND LAW 75-93 (2013).
} 
The upgoing curve in lawsuits related to the national health system was the trigger to initial rulings by the Federal Supreme Court ("Supremo Tribunal Federal", referred to as STF), that took into account the institutional capacity reasoning, reopening the debate on the deferential judicial approach to Executive choices.

\section{REASSESSING THE DEFERENTIAL APPROACH: INITIAL SIGNS BEFORE THE PANDEMIC}

Over the past two years, initial signs were seen in STF on reassessing a deferential judicial approach, especially in administrative regulation related to the right to health, and public services related to that same right.

Three decisions might be highlighted in that new trend.

The first ruling worth noticing was issued in abstract judicial review (ADI 4874) ${ }^{7}$ of a regulatory act issued by the National Agency on Sanitary Vigilance, therefore referred to as ANVISA. This agency oversees regulation in a broad range of health-adjecent issues - their role is similar to that of the Food and Drugs Administration, in the United States. The agency enacted a Resolution banning the usage of flavoring substances in cigarettes, considering that it will turn smoking more appealing, especially to the youth, which therefore made this practice a health hazard. The Justice Rapporteur, Rosa Weber, upholding the agency's decision evoked the Chevron precedent to assert that there was a legislative delegation, and that the agency regulated reasonably, among the limits of that same delegation.

This approach in line with the Chevron two-step test was not appealing to the Court at the occasion - at least, not enough to grant a majority. In fact, the result was a tie ${ }^{8}$, with the Justices dissenting on the extension of the legislative delegation to the agency, considering specifically the banning of products. The relevance of the precedent, despite the tie, is bringing the express consideration of a deferential approach to an Executive deliberation, considering the expertise of the administrative body to debate after a long time.

A second relevant precedent was issued in May 22 $2^{\text {nd }}, 2019$, in "Extraordinary Appeal" $n^{\circ} 657.718$ (literal translation of the Brazilian denomination "recurso extraordinário"), in which the Court was called to decide whether the State can be compelled to provide medication and medical procedures not yet approved by the aforementioned ANVISA. In a majority ruling, the

\footnotetext{
${ }^{7}$ Federal Supreme Court, ADI 4874, Justice Rapporteur Min. Rosa Weber, Plenary, February 1 ${ }^{\text {st }}$, 2018, DiÁRIO DA JUSTIÇA [D.J.], 01.02.2019.

${ }^{8}$ There are eleven Justices in the Brazilian Constitutional Court, but in that case, Justice Barroso was exempt, due to a previous legal opinion giver in the matter, before his nomination to the Court.
} 
Court decided that the public health system and its components - the agency included - is provided with institutional capacity to evaluate the adequacy on offering new medication or procedures. Such evaluation, according to the majority, should consider not only its real and proven effects over the illness, but also systemic effects, considering the Brazilian constitution asserts universality as a ruling principle applicable to the right to health.

The Court exempted the State from providing non-approved medication, if agency deliberation was in course and the legal established length of such analysis had not expired. Allowing judges all around the country to decide otherwise was considered unconscionable, due to the Judiciary's limited capacity to engage in such analysis.

A second precedent showing the Court's willingness to reassess judicial deference was also related to the right to health - another "Extraordinary Appeal" no 566.471 (BRASIL, 2020a), in which the central issue was the whether the State can be compelled to offer highcost medication whenever it was not listed in the "National Program of Exceptional Dispensation of Medication" - a public policy executed by the public health system ${ }^{9}$. Once again, through a majoritarian ruling, in March $11^{\text {th }}, 2020$, the Court evoked the expertise of the administrative components of the public health system in deciding if a medication, even if already approved by ANVISA, should be offered or not considering its high costs, and the evident trade-of inherent to such a decision. The Court also mentioned its incapacity to anticipate possible effects in the financial balance of the whole system, relying in the Executive adhesion to the constitutional commitment in granting a right to health.

These two last rulings are also based in the legal requirement that Executive decisions in the national health system should be grounded in "medicine based in evidence" (Federal Law 8080 and modified by Federal Law 12.401/11). The technical content of such a concept led the Court to assert that judicial review should not replace the administrative structures invested with such a scientific authority.

The path was open for reassessing the deferential approach debate - and then we found ourselves in the middle of a pandemic.

\section{PANDEMICS AND THE REAFFIRMATION OF THE JUDICIAL DEFERENTIAL APPROACH}

\footnotetext{
${ }^{9}$ Medication, exams, and procedures granted by the National Health System are offered by the distinct federative levels according to specific programs and protocols. Medication out of the ordinary - related to rare diseases, experimental substances and other non-orthodox hypothesis are offered by the central government, in the above-mentioned program.
} 
Experiencing the COVID-19 pandemic forces people and institutions to assess things differently. This is also true when it comes to judicial review in legislative and administrative choices. That new perspective is also powered by at least two changes brought by such perilous times.

The first relevant change, at least to the Brazilian understanding about judicial intervention in administrative strategical choices related to granting the right to health, is the absence of scientific certainty. The core concept of "medicine based in evidence" is no longer available, and Federal Law 13.979/20, regulating administrative measures in facing the pandemic refers to "strategical information in health". Ruling under uncertainty, STF shows clear discomfort in disregarding technical decisions designed by public agencies - therefore, the Court is visibly exercising self-constraint in recent rulings.

A second decisive component is that fact that the pandemic itself, due to it extension, demonstrates that public policies are clearly linked by interdependent relations. This is not a specific feature of the pandemic - everyone who deals with public policies can understand that there is a matrix in which various regulations, programs and strategies operate together. The novelty relies in such an understanding by the Judiciary, who usually tends to consider administrative choices in isolation. Internalizing that interdependency revealed to the Judiciary the risk in generating unforeseen or unintended effects whenever striking Executive deliberation.

It is certainly early to proclaim a substantive change in STF's view - but at least two recent decisions recall premises that aligned with the deferential approach.

The first one worth mentioning, was held in abstract judicial review of the Federal Law $\mathrm{n}^{\mathrm{o}}$ 13.979/20. The precept challenged, among other things, intended to concentrate in the central level, the definition of what administrative measures should be adopted in each State, among the list designed by that same law, which includes compulsory medical exams, social isolation, administrative requisition, etc. Justice Marco Aurelio in ADI $6341^{10}$ granted a partial injunction in order to establish that States and Municipalities - and not the central government - should define the proper and proportional measures to be held in each place. That partial injunction was upheld by the bench in a unanimous decision in April 16 ${ }^{\text {th }}, 2020$.

One can see that ruling as resolving a federative conflict, solved by the constitutional distribution of power among federation members. Even though that argument was relevant to

\footnotetext{
${ }^{10}$ Federal Supreme Court, ADI 6341, Justice Rapporteur: Min. Marco Aurélio, April 15, 2020, still not published.
} 
the ruling, the need to maintain adherence between the administrative measures to be taken and the real situation around the spreading of the virus was also repeatedly mentioned in the session. The case is particularly relevant, showing the Court's deference to the choices in both branches: the legislative deliberation to delegate to each member of the federation to decide according to its own situation related to virus contamination; and the administrative choices to be made, considering its proximity and expertise to decide when and what would be effective in their own area.

The second decision that illustrates a new sensibility to the deferential approach has held in ADI $6344^{11}$ relates to Provisional Measurement $927^{12}$ - from now on, identified as MP 927. Here, the Executive branch proposed possible measures to be taken by employers to their employees, related to preserve jobs and business operation. Those measures can include changes in working regime (allowing home office, reducing job hours, etc.); anticipating vacations, salary reduction, and many other possibilities. For some of these, MP 927 required an agreement between employer and employees; others, on the other hand, could be implemented unilaterally by the employer, innovating in a traditionally very protective legal framework in labor relations.

MP 927 was challenged by labor unions who claimed that it expressed regression in protecting workers social rights. In a majority ruling -6 in favor, 4 dissenting - the Court upheld most part of the Executive order. Two main considerations prevail: 1) the Executive order, according to the legislative procedure, would also have to be submitted to the Legislative branch, which should appreciate the political choice it expressed; and 2) the pandemic involves crafting an intricate balance between multiple institutional arrangements and extensive normative frameworks regulating distinct areas. The combination of the two recommend a selfrestraining disposition, and deference, once again, to both other branches: the Executive, who proposed MP 927, and the Legislative, who was entitled to examine freely the proposition.

\section{Can we proclaim a neW trend in the Court's usage of the deferential APPROACH?}

\footnotetext{
${ }^{11}$ Federal Supreme Court, ADI 6344, Justice Rapporteur: Min. Marco Aurélio, April 29, 2020, still not published.

12 The Brazilian Constitution contains a legislative tool, called "Medida Provisória" (in a literal translation, "Provisional Measure") that can be edited by the Executive branch, with force of law. That "Provisional Measure" is supposed to be appreciated by the Legislative branch in 60 days, extendable for more 60 days. Non deliberation in that period is equivalent to rejection, and in both cases - non deliberation or rejection - Congress should regulate the legal effects of during the validity period.
} 
Resistance to the deferential approach, as mentioned in the beginning, has historical roots. ${ }^{13}$ It is understandable that such a vision will not change in a single ruling, as long as it involves reassessing the whole balance between the power branches.

The decisions held before the pandemic already expressed initial signs of a Court's new perception according to which complex systems might be better served by honoring each organization institutional design and expertise. Therefore, the turning point was not exactly the pandemic - but living in that scenery of uncertainty highlighted the risks on replacing technical deliberation drafted in the Executive branch, by subjective perceptions from a Court's Justice.

Executive strategies, especially in public policies, frequently involve distributional decisions that can lead to tragic choices. ${ }^{14}$ This comes from the very nature of the whole human rights protection project - and it is not enough reason to discard the deferential approach in judicial review. Deference will never mean blockage to judicial control against an Executive choice that deviate from the constitutional commitments traced to the State. But it can provide a dialogical scrutiny of administrative reasoning, enhancing a right to justification which is inherent to a democratic society.

\section{LIST OF ABBREVIATIONS}

ADI - Ação Direta de Inconstitucioanlidade [Direct Action of Unconstitutionality] ANVISA - Agência Nacional de Vigilância Sanitária [National Agency on Sanitary Vigilance] COVID-19 - Corona Virus Disease 2019

MP - Médida Provisória

STF - Supremo Tribunal Federal [Federal Supreme Court]

SUS - Sistema Único de Saúde [Unified Health System]

\section{REFERENCE LIST}

CONSELHO NACIONAL DE JustiÇA, JustiÇA EM NúMEROS 2019 (2019).

Daniel Wl Wang, Courts and health care rationing: the case of the Brazilian Federal Supreme Court, 8 HEALTH ECONOMICS, POLICY AND LAW 75-93 (2013).

\footnotetext{
${ }^{13}$ Vanice Lírio do Valle, Judicial deference and public policy: respecting the boundaries, 22 JURIS POIESIS - SEÇão ESPECIAL 338-44 (2019).

14 Guido Calabresi \& Philip Bobbitt, Tragic choices: The conflicts society confronts in the allocation of TRAGICALLY SCARCE RESOURCES (1978).
} 
Estefania Maria de Queiroz Barboza \& Katya Kozicki, Judicalization of Politics and the Judicial Review of Public Policies by the Brazilian Supreme Court, 13 DIRITTO \& QUESTIONI PUBBLICHE 407-44 (2013).

Federal Supreme Court, ADI 4874, Justice Rapporteur Min. Rosa Weber, Plenary, February 1st., 2018, DiÁRIO DA JUSTIÇA [D.J.], 01.02.2019.

Federal Supreme Court, ADI 6341, Justice Rapporteur: Min. Marco Aurélio, April 15, 2020, still not published.

Federal Supreme Court, ADI 6344, Justice Rapporteur: Min. Marco Aurélio, April 29, 2020, still not published.

Federal Supreme Court, RE 566471 RG, Justice Rapporteur: Min. Marco Aurélio, March 11, 2020, still not published.

Federal Supreme Court, RE 657718 AgR, Justice Rapporteur: Min. Marco Aurélio, Justice designated to write the ruling: Roberto Barroso, Plenary, May 22, 2019, still not published.

Guido CALABREsi \& Philip BobBitT, TRAgiC CHOICES: THE CONFLICTS SOCIETY CONFRONTS IN THE ALLOCATION OF TRAGICALLY SCARCE RESOURCES (1978).

Lei $\mathrm{n}^{\mathrm{o}} 13.979,6$ de fevereiro de 2020, Dispõe sobre as medidas para enfrentamento da emergência de saúde pública de importância internacional decorrente do coronavírus responsável pelo surto de 2019, DiÁRIO OFICIAL DA UNIÃo [D.O.U], de 07.02.2020 (Braz.).

Luís Roberto Barroso et al., Developments in Brazilian constitutional law: The year 2016 in review, 15 INTERNATIONAL JOURNAL OF CONSTITUTIONAL LAW 495-505 (2017).

Medida provisória $\mathrm{n}^{\circ} 927$, de 2020, Dispõe sobre as medidas trabalhistas para enfrentamento da emergência de saúde pública decorrente do coronavírus, 2020 (Braz.).

Rogério B. Arantes, Constitutionalism, the Expansion of Justice and the Judicialization of Politics in Brazil, in THE JUdICIALIZATION OF POLITICS IN LATIN AMERICA 231-62 (Rachel Sieder; Line Schjolden \& Alan Angell eds, 2005).

Vanice Lírio do Valle, Judicial deference and public policy: respecting the boundaries, 22 JURIS POIESIS - SEÇÃo ESPECIAL 338-44 (2019). 


\title{
Judicial Review and the Politico-legal Constitution
}

\author{
Anne Richardson Oakes ${ }^{1}$ \\ Birmingham City University, United Kingdom
}

\begin{abstract}
The decision of the British people in 2016 that the U.K. should leave the European Union has inaugurated a period of intense debate concerning the future development of the U.K.'s notoriously 'flexible' constitutional arrangements and specifically the relationship between Montesquieu's three branches of government, the legislature, the executive and the judiciary. The decisions of the U.K. Supreme Court in R. (Miller) v. Secretary of State for Exiting the European Union and R. (Miller) v. Prime Minister provoked widespread anger and political commitments to curb judicial overreach. This paper reflects on the implications for the future development of judicial review in U.K. constitutionalism. It notes that attempts to mine the common law heritage for constitutional principles may indicate attempts by the U.K. Supreme Court to anticipate U.K. withdrawal from the jurisdiction of the European courts but suggests that in a turbulent political climate, judicial review will do well to refocus away from the constitutionalism of recent years in favour of a more traditionally restrained role that will demonstrate respect for the political choices of the electorate's chosen representatives
\end{abstract}

Keywords: Legal Constitutionalism, R.(Miller) v. Secretary of State for Exiting the European Union, R. (Miller) v. Prime Minister.

Contents: 1. Introduction. 2. Towards a Legal Constitution. 3. Rebalancing the Separation of Powers in a Politico-Legal Constitution.

\section{INTRODUCTION}

The decision of the British people in 2016 that the U.K. should leave the European Union has inaugurated a period of intense debate concerning the future development of the U.K.'s notoriously 'flexible' constitutional arrangements and specifically the relationship between Montesquieu's three branches of government, the legislature, the executive and the judiciary. The decision of the Cameron administration to hold what was only the third ever referendum was widely criticised at the time on the basis that the commitment to popular sovereignty that it represented sits uneasily with the constitutional orthodoxy of parliamentary sovereignty. However, it was the political turmoil that followed the implementation attempts by Prime Minister May and her successor Boris Johnson that brought the judiciary into the fray

\footnotetext{
${ }^{1}$ Director, Centre for American Legal Studies, Birmingham City University. Anne.oakes@bcu.ac.uk
} 
and produced what are widely regarded as the two most important constitutional rulings of our time. The decisions of the Supreme Court that the U.K. government had acted unlawfully in its decisions to initially trigger Article 50 without recourse to Parliament ${ }^{2}$ and then, more recently, to prorogue Parliament itself $f^{3}$ provoked accusations of judicial overreach and widespread anger in Conservative party circles now reflected in a manifesto promise of judicial review reform that will "restore trust in our institutions and in how our democracy operates" and "ensure that judicial review is available to protect the rights of the individuals against an overbearing state, while ensuring that it is not abused to conduct politics by another means or to create needless delays."4

What exactly the Conservative government has in mind remains to be seen. At the time of writing the promised Constitution, Democracy \& Rights Commission has yet to materialise. However, taken in conjunction with proposals to "update" the Human Rights Act 1998 which incorporates the European Convention on Human Rights into U.K. law and now grounds many judicial review challenges brought against government policies, the concern is expressed that what is at issue here is a politically motivated desire for revenge intended to clip the wings of the judiciary and thereby threaten judicial independence and with it the rule of law. ${ }^{5}$ As Professors Harlow and Rawlings point out, these threats are not without precedent. ${ }^{6}$ The Criminal Justice and Courts Act 2015 in combination with changes to the Civil Procedure Rules introduced significant restrictions on the availability of judicial review proceedings motivated by a perception that "judicial review has become too much of a political tool of opposition to government policy." "In the words of then Justice Secretary Chris Grayling, judicial review should not be "a promotional tool for countless Left-wing campaigners." 8

It is common to reject assertions of judicial politicisation as misplaced because they conflate the nature of the court's decision which is concerned with process with the political merits of of the decision which is under review. As has been pointed out, "all judicial review proceedings are the result of politics of some kind [...] [and] no claimant bringing a judicial review ever agrees with substantive decision that they are challenging — they simply wouldn't

\footnotetext{
${ }^{2}$ R. (Miller) v. Secretary of State for Exiting the European Union [2017] UKSC 5 (Miller I).

${ }^{3}$ R. (Miller) v. Prime Minister [2019] UKSC (41) (Miller II).

${ }^{4}$ Conservative \& Unionist Party Manifesto 48 (2019).

5 See Jane Croft \& James Blitz, Lawyers Fear Tories Are Planning 'Revenge' Against the Supreme Court, FinanCIAL TimES (Dec. 11, 2019).

${ }^{6}$ Carol Harlow \& Richard Rawlings, 'Striking Back' and 'Clamping Down': An Alternative Perspective on Judicial Review, in Public Law Adjudication in Common Law Systems: Process and Substance 312 (John Bell et al. eds., 2015).

${ }^{7}$ Constitution Committee, Criminal Justice and Courts Bill, HL 18 (2014) [6].

${ }^{8}$ Chris Grayling, The Judicial Review System is not a Promotional Tool for Countless Left-wing Campaigners, DAILY MAIL (Sept. 6, 2013).
} 
bother otherwise." What is important, however, is the statement that follows: "the Courts ... determine such proceedings on the basis of the lawfulness of the public decision, not its substance. And that is the beginning and end of judicial review - it is a supervisory process to ensure that public decisions are taken lawfully, not a means for the Court to substitute its own judgement for that of the decision-maker." 10 As a statement of constitutional orthodoxy this is an uncontroversial acknowledgment that the judicial role vis à vis the political decisions of the executive should be one of respect for, or deference to, the choices of the people's elected representatives or those answerable to them. In terms of practical application, however, the history of the development of judicial review in the U.K. since 1978 suggests that the line between supervision of process and review of substance is easily crossed and indeed in many cases should be crossed if the requirements of U.K. human rights law obligations are to be satisfied. The point then for this paper is that, for its detractors, judicial review has become and is seen to have become insufficiently 'deferential' and thereby overstepped the boundaries of its constitutional role.

\section{TOWARDS A Legal CONSTITUTION}

The U.K. famously has no written Constitution. In its absence, traditional orthodoxy describes the constitution of the United Kingdom as political rather than legal ${ }^{11}$ because the primary channels of governmental accountability run to the legislature via political mechanisms of control, as opposed by the judiciary. ${ }^{12}$ In the words of Professor Tomkins, "[a] political constitution is one in which those who exercise political power (let us say the government) are held to constitutional account through political means, and through political institutions (for example, Parliament)." In contrast, a legal constitution is “one which imagines that the principal means, and the principal institution, through which the government is held to account is the law and the court-room."13 While it is true that in terms of our constitutional history, the tension between the political and legal institutional mechanisms of accountability has been resolved in favour of the former, it is also true that the development of a review

\footnotetext{
${ }_{9}^{9}$ See Michael Dempsey, General Election 2019: Judicial Review Reform for Brexit Britain? BRYAN CAVE LEIGHTON PAISNER (Dec.3, 2019).

${ }^{10} I d$.

${ }^{11}$ See, e.g., Graham Gee \& Gregoire C.N. Webber, What Is a Political Constitution? 30 Oxford J. Leg. Studies 273 (2010); Adam Tomkins, In Defence of the Political Constitution, 22 OXFord J. LeG. STUDIES 157 (2002); Adam Tomkins, What's Left of the Political Constitution, 14 GERMAN L.J. 2275 (2013).

${ }^{12}$ See Adam Tomkins, Public Law 18-19 (2003).

${ }^{13} I d$.
} 
jurisprudence for the protection of fundamental rights which anticipated but predated the coming into effect of the Human Rights Act 1998 has materially shifted the balance. The willingness of the U.K. Supreme Court to deploy the common law heritage in this endeavour may be explained in terms of prescience and expediency-as Professor Elliott observes, the effect of recent case law is that

it is hard to resist concluding that senior judges are laying the ground for possible HRA repeal and ECHR withdrawal, and that, in doing so, they are ensuring that the underlying common law landscape that would be laid bare in such circumstances would turn out to embody a set of human rights protections comparable to those that obtain today 14

In constitutional terms the overall effect indicates a significant change of emphasis in favour of the legal constitution, ${ }^{15}$ albeit without its ultimate sanction - no judge has as yet attempted to declare an Act of Parliament to be unconstitutional. ${ }^{16}$

\section{Rebalancing the Separation of Powers in a Politico-Legal Constitution}

As the fallout from the Miller judgments continues to make waves, ${ }^{17}$ this paper considers the position of the judiciary vis à vis the executive from the perspective of what Professor Richard Mullender identifies as a "dispositional" element in the U.K. constitutional order This, he claims, "finds expression in the effort to identify contingencies (most obviously, internal and external threats) that may disrupt the order's operations or even compromise its

\footnotetext{
${ }^{14}$ Mark Elliott, Revising for your 2014 Public Law exam? Here are some of this year's key developments and blog highlights, Public LAw For Everyone (May 7, 2014).

${ }^{15}$ See Lord Hoffman in R. v. Secretary of State for the Home Department ex parte Simms, [2000] 2AC 115, 131 (claiming that "the courts of the United Kingdom, though acknowledging the sovereignty of Parliament, apply principles of constitutionality little different from those which exist in countries where the power of the legislature is expressly limited by a constitutional document."

${ }^{16}$ In C-221/89 R. Secretary of State v. Factortame [1991] ECJ the European Court of Justice (ECJ), now the Court of Justice of the European Union (CJEU) was asked to consider whether the U.K. Merchant Shipping Act 1998 was incompatible with EC law. The Court ruled that in such circumstances a national court has a duty to grant interim relief to safeguard alleged Community rights of individuals until the decision of the ECJ on the interpretation of Community law is available, and where a rule of national law would deny such relief, to set aside that rule. The U.K. House of Lords subsequently granted Factortame an injunction in effect disapplying the relevant provisions of the 1998 Act. In Jackson v. Attorney General [2006] 1 AC 262 at [102] Lord Steyn opined obiter that if Parliament were to introduce "oppressive and wholly undemocratic legislation"-as for example, by moving to abolish judicial review - then the judges who had created the principle of parliamentary sovereignty might have qualify it, i.e. they might have to consider whether judicial review "is a constitutional fundamental which even a sovereign Parliament acting at the behest of a complaisant House of Commons cannot abolish."

17 See Jessica Semor Q.C., Is the Civil Law Interpretation of Proportionality Causing the Court to Become Political and Therefore Harder to Predict?, White PaPer Conference, Judicial Review: Shaping New Law into Solution-Focused ANSWERS FOR YOUR CLIENTS (Apr. 18, 2018).
} 
viability." 18 Attentiveness to these matters "prompts those who cultivate it to keep a weather eye on sources (or potential sources) of practical difficulty." ${ }_{19}$ From this point of view, the Miller judgments with their emphasis on common law principles of rights protection and legality prioritised the legal arguments rather than the political ${ }^{20}$ but stand accused of misjudging contemporary democratic imperatives. As Lord Reed pointed out in his Miller I dissent, "[i]t is important for courts to understand that the legalisation of political issues is not always constitutionally appropriate, and may be fraught with risk, not least for the judiciary." 21

This paper now predicts and comments as follows. Writing in 2018 before the U.K. formally left the European Union, Professor Mullender's focus was Brexit and the changing constitutional relationship between law and politics that Miller I specifically and subsequently Miller II represented. As the coronavirus pandemic sweeps across the globe, and governments, including those of the U.K. use emergency powers to legitimise restrictions on economic and social activity not seen outside of war, Carol Harlow \& Richard Rawlings' well-known comment - "Behind every theory of administrative law there lies a theory of the state" 22 has never been more apposite. The judiciary will almost certainly be called upon to "show the red light' to government actions that infringe individual rights but the constitutional pendulum will be reset and the tension between the judicial and elected branches inherent in the U.K. version of the separation of powers will be resolved in favour of the latter. Judicial review will refocus away from the constitutionalism of recent years in favour of a more traditionally restrained role that will demonstrate respect for the political choices of the electorate's chosen representatives. In this respect, the refusal of the Supreme Court in the recent case of Gallaher ${ }^{23}$ to develop a common law principle of equal treatment may represent a straw in the wind. Lord Carnwath cited with approval the remarks of Lord Hoffmann in the earlier case of Matadeen $v$ Pointu $^{24}$ who framed the issue thus:

Of course persons should be uniformly treated, unless there is some valid reason to treat them differently. But what counts as a valid reason for treating them differently? And, perhaps more important, who is to decide whether the reason is valid or not? Must it always be the courts?

\footnotetext{
${ }^{18}$ Richard Mullender, Transmuting the Politico-Legal Lump: Brexit and Britain's Constitutional Order, 39 CARDOZO L. REV. 1019 (2018).

${ }^{19}$ Id. At 1038 .

${ }^{20}$ In Miller I no judge expressed the view that the matter was non-justiciable.

${ }^{21} \mathrm{R}$ (Miller) v. Sec'y of State for Exiting the European Union (Miller 1) [2017] UKSC 5 [240] (Lord Reed, JSC, dissenting).

${ }^{22}$ Carol Harlow \& Richard Rawlings, Law AND Administration 46 (3d ed. 2009).

${ }^{23}$ R (Gallagher Group Ltd.) v. Competititon \& Markets Auth. [2018] UKSC 25 [26].

${ }^{24}$ [1999] 1 AC 98 [9] (Lord Hoffmann) (internal citation omitted).
} 
The reasons for not treating people uniformly often involve, as they do in this case, questions of social policy on which views may differ. These are questions which the elected representatives of the people have some claim to decide for themselves. The fact that equality of treatment is a general principle of rational behaviour does not entail that it should necessarily be a justiciable principle — that it should always be the judges who have the last word on whether the principle has been observed. In this, as in other areas of constitutional law, sonorous judicial statements of uncontroversial principle often conceal the real problem, which is to mark out the boundary between the powers of the judiciary, the legislature and the executive in deciding how that principle is to be applied.

As former Supreme Court Justice Jonathan Sumption has observed, this is not a matter of deference but rather a function of two distinct sources: "[o]ne is the constitutional principle of the separation of powers. The other is simply a pragmatic view of the evidential value of some judgments of the executive, in areas where their experience is entitled to weight." 25

Former Law Lord and House of Lords cross bencher Lord Brown of Eaton-underHeywood asserted in the course of debate on the Criminal Justice and Courts Bill that judicial review is not a matter for the legislature. ${ }^{26} \mathrm{With}$ all respect, in our mixed politico-legal order it is the doctrine of the sovereignty of Parliament which in the last analysis will and should give Parliament the upper hand. Parliament has determined on two significant occasions that the scope of judicial review is too important to be left entirely to the judges. ${ }^{27}$ While the second intervention was regarded by members of the senior judiciary as misguided, it is certainly the case that it was the first intervention that marked the beginning of a systemised jurisdiction of judicial review as we know it today and from that point of view must be regarded as positive. In the same way there are choices to be made concerning the allocation of resources and the differential treatment of persons, as above. In a modern democracy these matters are too important to be left entirely to the judges.

\footnotetext{
${ }^{25}$ Lord Sumption, Lord Sumption gives the Administrative Law Bar Association Annual Lecture; Anxious Scrutiny (Nov. 4, 2014).

${ }^{26}$ HL Deb vol 755 col 1440 (28 July 2014), Lord Brown of Eaton-under- Heywood.

27 The new procedure of Application for Judicial Review was introduced initially by changes to civil procedure rules-see SI 1977 No 1955; SI 1980 No 2000 - and is now found in the Senior Courts Act 1981, s 31. The Criminal Justice and Courts Act 2015, Part 4 introduced significant changes to the procedure which have the effect of making it more difficult for charities and campaigning groups to intervene in judicial review proceedings. Notably, under S87 interveners in judicial review proceedings must bear the consequential costs of intervention if :a) the intervenor acts "in substance" as a principal party or b)their intervention is not of "significant assistance" or c) a "significant part" of the intervention is "not necessary for the resolution of the issues" or d) the intervenor has behaved unreasonably". Under S 84 a court "must" refuse to grant permission or relief if it is "highly likely" that he public authority would have made the same decision if it had acted lawfully.
} 


\section{LIST OF ABBREVIATIONS}

CJEU - Court of Justice of the European Union

ECHR - European Court of Human Rights

ECJ - European Court of Justice

HRA - Human Rights Act 1998

\section{REFERENCE LIST}

Adam Tomkins, In Defence of the Political Constitution, 22 OXFORD J. LEG. STUDIES 157-75 (2002).

ADAM TOMKINS, PUBLIC LAW (2003).

Adam Tomkins, What's Left of the Political Constitution, 14 GERMAN L.J. 2275-292 (2013).

C-221/89 R. Secretary of State v. Factortame [1991] ECJ.

Carol Harlow \& Richard Rawlings, 'Striking Back' and 'Clamping Down': An Alternative Perspective on Judicial Review, in PUBLIC LAW ADJUDICATION IN COMMON LAW SYSTEMS: PROCESS AND SubSTANCE 312 (John Bell et al. eds., 2015).

CAROL HARlOW \& RichaRd RAWLings, LAw AND AdMINISTRATION 46 (3rd ed. 2009).

Chris Grayling, The Judicial Review System is not a Promotional Tool for Countless Left-wing Campaigners, DAILY MAIL (Sept. 6, 2013), https://www.dailymail.co.uk/news/article-2413135/CHRISGRAYLING-Judicial-review-promotional-tool-Left-wing-campaigners.html

CONSERVATIVE \& UNIONIST PARTY MANIFESTO (2019), https://assets-global.websitefiles.com/5da42e2cae7ebd3f8bde353c/5dda924905da587992a064ba_Conservative\%202019 $\% 20$ Manifesto.pdf.

Constitution Committee, Criminal Justice and Courts Bill, HL 18 (2014) [6].

Graham Gee \& Gregoire C.N. Webber, What Is a Political Constitution? 30 OXFORD J. LEG. STUDIES 273-99 (2010).

HL Deb vol 755 col 1440 (28 July 2014), Lord Brown of Eaton-under- Heywood.

Jackson v. Attorney General [2006] 1 AC 262 at [102].

Jane Croft \& James Blitz, Lawyers Fear Tories Are Planning 'Revenge' Against the Supreme Court, FinANCIAL TiMES (Dec. 11, 2019), https://www.ft.com/content/60f97382-1b4e-11ea-97dfcc63de1d73f4.

Jessica Semor Q.C., Is the Civil Law Interpretation of Proportionality Causing the Court to Become Political and Therefore Harder to Predict? WhITE PAPER CONFERENCE, Judicial REVIEW: SHAPING New LAW INTO SOLUTION-FoCUSED ANSWERS FOR YOUR CLIENTS (Apr. 18, 2018), https://www.matrixlaw.co.uk/wp-content/uploads/2016/03/Does-the-proportionalitytest-make-judges-too-political.pdf.

Lord Sumption, Lord Sumption gives the Administrative Law Bar Association Annual Lecture; Anxious Scrutiny (Nov. 4, 2014), https://www.supremecourt.uk/docs/speech-141104.pdf. 
Mark Elliott, Revising for your 2014 Public Law exam? Here are some of this years's key developments and blog highlights, PUBLIC LAW FOR EVERYONE (May 7, 2014), https://publiclawforeveryone.com/2014/05/07/revising-for-your-public-law-exam-here-aresome-of-this-years-key-developments-and-blog-highlights/

Matadeen v Pointu [1999] 1 AC 98 [9] (Lord Hoffmann) (internal citation omitted).

Michael Dempsey, General Election 2019: Judicial Review Reform for Brexit Britain? BRYAN CAVE LEIGHTON PAISNER (Dec. 3, 2019), https://www.bclplaw.com/en-GB/thoughtleadership/general-election-2019-judicial-review-reform-for-brexit-britain.html.

R (Gallagher Group Ltd.) v. Competititon \& Markets Auth. [2018] UKSC 25 [26].

R (Miller) v. Sec'y of State for Exiting the European Union (Miller 1) [2017] UKSC 5 [240].

R. (Miller) v. Prime Minister [2019] UKSC (41) (Miller II).

R. (Miller) v. Secretary of State for Exiting the European Union [2017] UKSC 5 (Miller I).

R. v. Secretary of State for the Home Department ex parte Simms, [2000] 2AC 115, 131.

Richard Mullender, Transmuting the Politico-Legal Lump: Brexit and Britain's Constitutional Order, 39 CARDOZO L. REV. 1019-038 (2018).

The Criminal Justice and Courts Act 2015. 


\title{
THe Role OF Policy IN THE EXERCISE OF Discretion: A COMPARATIVE SEARCH FOR FAIRNESS
}

\author{
Friso Jansen ${ }^{1}$ \\ Birmingham City University, United Kingdom
}

\begin{abstract}
The executive in implementing the wishes of parliament is often faced with a problem of allocation. How to distribute limited resources and exercise the discretion afforded to the executive in such a way that this is both procedurally and substantively fair? The answer lies in the formulation of a policy. Through clear and transparent procedures citizens would be treated equally, therefore delivering administrative justice. Different countries, however, seem to prioritize different conceptions of fairness and equality. While in English administrative law the focus is placed on the need for a scrutiny of the individual circumstances of a claimant to avoid fettering discretion in Dutch administrative law the stress is placed on the claimant to prove he should be treated differently to the standard case envisaged in a policy document. The question becomes whether on closer inspection these theoretical differences in approach reveal differences in practical application. This paper will try to answer some of these questions based on a comparative reading of law and jurisprudence from both countries.
\end{abstract}

Keywords: discretion, policy rules, fairness.

Content: 1. Policy Rules in the Netherlands: The General Administrative Law Act Reviewed. 2. Fettering Discretion: Restraining Decision-Makers Through Development of the Common Law. 3. Auer Deference: A Striking Absence. 4. The Exercise of Discretion: Is Achieving Fairness an Impossible Dream?

\section{Policy Rules in the Netherlands: The General Administrative LaW Act REVIEWED}

Exercise of discretion by an administrative decision-maker to award a permit, give a subsidy, award benefits etc. is in many cases restricted through three overlapping mechanisms: the existence of policy promulgated by the decision maker, the existence of policy rules (beleidsregels) that provide detail on how the decision maker will apply the policy and the general principles of good administration (algemene beginselen van behoorlijk bestuur) that govern the exercise of discretion. The relationship between these three layers is complex and the way the judiciary evaluates the exercise of discretion is developing. The codification of policy rules in article 4:84 of the General Administrative Law Act (Algemene Wet

\footnotetext{
${ }^{1}$ Associate Director, Center for Law Science \& Policy, Birmingham City University. Friso.Jansen@bcu.ac.uk
} 
Bestuursrecht) (GALA) has led to a large increase in their use. The GALA requires that a decision maker follows its policy rules in all cases, thereby treating everyone in accordance with the principle of equality — one of the general principles of good administration. However, if maintaining the policy rules in an individual case leads to consequences for the applicant that are disproportionate in relation to goals of the policy rules the decision maker must deviate from the policy rules. ${ }^{2}$ This is described as the inherent power to deviate (inherente afwijkingsbevoegdheid). The circumstances in which this deviation can occur are strictly prescribed; the applicant would need to make a very compelling case that his or her circumstances are exceptional. The courts give the decision maker a wide latitude in deciding whether a case is so exceptional as to warrant the use of the inherent power to deviate from the policy rules. ${ }^{3}$ Recently, however, the Administrative Jurisdiction Division of the Council of State (Afdeling Bestuursrechtspraak van de Raad van State) has been more exacting and required the decision-maker to give a detailed motivation about why they did not allow an exception, even though the case of the applicant was not one in which the policy rules envisaged the discretion to award a permit would be exercised. ${ }^{4}$

This increasing intensity of judicial scrutiny is interesting, and shows a shift in the appreciation of the role of the various powers in the trias politica. Traditionally the judiciary would be wary of encroaching upon the exercise of executive discretion, fearing that in this way they would disrupt the democratic process. ${ }^{5}$ The idea of Wednesbury Unreasonableness is comparable albeit not identical.

Over the years this traditional idea was replaced by the notion that the legislator was leaving more and more powers to the discretion of the executive, thereby reducing the political legitimacy of the decisions of the executive. In addition, the increasing number of decisions taken by the executive, a result of the increasing reach of the welfare state, meant that fewer and fewer decisions were subject to direct or indirect democratic control. In addition the legislator required the administrative judges to do more to make sure that disputes would be definitely resolved, rather than referring the decision back to the executive. ${ }^{6}$ The outcome of these various political and societal developments is that administrative judges strive to provide

\footnotetext{
${ }^{2}$ Art. 4.84 section 3 GALA.

${ }^{3}$ ECLI:NL:RVS:2000:AN6745,Administrative Jurisdiction Division of the Council of State (Sept. 26, 2000).

${ }^{4}$ ECLI:NL:RVS:2017:1314, Administrative Jurisdiction Division of the Council of State (May 17, 2017) with annotation AB 2017/270 H.E. Broring.

${ }^{5}$ Rolf Ortlep \& Wouter Zorg, Van Marginale Rechterlijke Toetsing naar Toetsing op Maat: Einde van een Geconditioneerde Respons? ARS AEQUi 20 (2018).

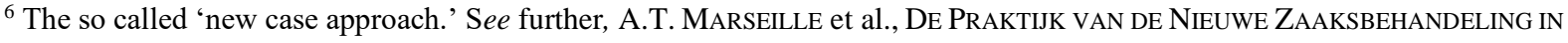
HET BESTUURSRECHT (2015).
} 
more support to citizens that challenge the exercise of discretion by decision-makers and more frequently than before try to encourage the executive to achieve substantive equality, by adequately considering all the individual circumstances of applicants. In this way, they push for decision-making that is more than mechanical application of policy rules but rather maatwerk, decisions that are made to fit each individual applicant.

\section{FetTERING Discretion: Restraining DeCision-Makers Through DEVELOPMENT OF THE COMMON LAW}

Fettering discretion would occur if a policy was inflexible and did not allow for exceptions in the exercise of discretion by an administrative decision-maker. Such a policy would be unlawful as the individual circumstances of an applicant could not be taken into account. Where in the Netherlands the GALA always allows decision-makers to depart from their policy rules if the circumstances warrant it, common law requires that decision maker states this explicitly in the policy to avoid a charge of fettering discretion. ${ }^{7}$ At first sight this might seem to imply that English administrative law values flexible decision-making that is tailored to individual circumstances of all applicants as fair, closely connected to the underlying principle of substantive equality of applicants. This would stretch the role of fettering discretion too far. Instead in English administrative law the legal certainty that the enactment of a policy brings and the consistent application of policy are equally prized as important elements of the rule of law. ${ }^{8}$ This tension between consistency to allow for legal certainty, and specificity to individual circumstances to achieve fairness is a known tension in public law. The way in which the courts try to balance these two aims is through requiring the decision-maker to have a good reason for departing from the policy. ${ }^{9}$ The quality of the reasons for departure, and here a closely parallel lies with the Dutch experience, is the main focus of judicial control.

The conceptual tree English judges use to justify a development of a ground of judicial review is of course the rule of law. A similar tendency can be observed in that the judiciary increasingly intensifies scrutiny by requiring the decision-maker to provide more compelling reasons, more extensive factual support, or a combination of these before certifying a decision as lawful.

\section{Auer Deference: A Striking AbSence}

\footnotetext{
${ }^{7}$ R. v. Hampshire CC ex p. W [1994] E.L.R. 460.

${ }^{8}$ R. (Alvi) v. Sec'y of State for the Home Dep't [2012] UKSC 33; R. v. Min. of Agric., Fisheries \& Food, ex p. Hamble (Offshore) Fisheries Ltd. [1995] 2 All E.R. 714.

${ }^{9}$ R. (Munjaz) v. Mersey Care NHS Trust [2006] 2 A.C. 148.
} 
An interesting aside is the striking contrast with the deference doctrines in the USA, where policy rules (regulations) that interpret the application of the law are shown deference by the court if the law is ambiguous and the interpretation by the executive in the regulation is not unreasonable. ${ }^{10}$ The reason that both England and The Netherlands do not know such a form of deference - policy rules that interpret the law do exist but they are not seen as in any way binding upon the court - is likely partly due to the different position of the executive. In the USA however, through the president the executive has direct democratic legitimacy, and through confirmation by the senate of key positions in the bureaucracy there is added democratic legitimacy for decision-makers.

\section{THE EXERCISE OF Discretion: IS ACHIEVING FAIRNESS AN IMPOSSIBLE DREAM?}

Both England and the Netherlands try to achieve the goal of fairness in tying the exercise of discretion by administrative decision-makers to the rule of law and allowing judicial scrutiny of their exercise. Starting from two very different historical starting points it becomes clear that the solutions to the problem of the tension between the general interest and the interests of the individual are strikingly similar. In both traditions increased judicial scrutiny has run parallel with a decrease in democratic legitimacy of the executive, compelling a need to protect the citizen against an overbearing state. The line between a valid rejection of a citizen as not falling within the rules and an oppressive decision that arbitrarily and therefore unlawfully withholds a benefit is one that is drawn over and over again. Recent jurisprudence shows that, against a backdrop of increasing Europeanisation, the free room for the executive to strike a bargain between the various interests at stake has been eroded. Deference to the executive has not disappeared but the executive faces increasingly critical scrutiny.

\section{LIST OF ABBREVIATIONS}

GALA - General Administrative Law Act (Algemene Wet Bestuursrecht)

\section{REFERENCE LIST}

\footnotetext{
${ }^{10}$ See Auer v. Robbins, 519 U.S. 452 (1997); Kisor v. Wilkie, 588 U.S.__ (2019). See also Chevron U.S.A., Inc. v. Natural Resources Defense Council, Inc., 467 U.S. 837 (1984); Mayo Found'n for Medical Science \& Research v. United States, 562 U.S 44 (2010); United States v. Mead Corp., 533 U.S. 218 (2001).
} 
A.T. Marseille et al., De PraktiJK VAn DE Nieuwe ZaAKsbehandeling in HeT BESTUURSRECHT

https://prettigcontactmetdeoverheid.nl/sites/default/files/documenten/BZK\%20NZB\%20Rapp ort\%20pdf.pdf

Auer v. Robbins, 519 U.S. 452 (1997).

Chevron U.S.A., Inc. v. Natural Resources Defense Council, Inc., 467 U.S. 837 (1984).

ECLI:NL:RVS:2000:AN6745, Administrative Jurisdiction Division of the Council of State (Sept. 26, 2000).

ECLI:NL:RVS:2017:1314, Administrative Jurisdiction Division of the Council of State (May 17, 2017).

General Administrative Law Act (Algemene Wet Bestuursrecht).

Kisor v. Wilkie, 588 U.S. (2019).

Rolf Ortlep \& Wouter Zorg, Van Marginale Rechterlijke Toetsing naar Toetsing op Maat: Einde van een Geconditioneerde Respons?' ARS AEQUI 20-25 (2018).

Mayo Found'n for Medical Science \& Research v. United States, 562 U.S 44 (2010).

R. v. Hampshire CC exp. W [1994] E.L.R. 460.

R. (Alvi) v. Sec'y of State for the Home Dep't [2012] UKSC 33.

R. v. Min. of Agric., Fisheries \& Food, ex p. Hamble (Offshore) Fisheries Ltd. [1995] 2 All E.R. 714.

R. (Munjaz) v. Mersey Care NHS Trust [2006] 2 A.C. 148.

United States v. Mead Corp., 533 U.S. 218 (2001). 